\title{
Territorio sagrado de Pariaqaqa en los distritos sureños de Huarochirí
}

\author{
Sabino Arroyo Aguilar \\ sabinoarroyo@hotmail.com \\ Departamento de Antropología. UNMSM
}

\begin{abstract}
Resumen
Los distritos sureños de Huarochirí siguen preservando la simbología de Pariaqaqa, como dios del agua, vinculada a las cualidades de las ñustas de sus ancestros que se asocian con los actuales sitios arqueológicos contiguos a los pueblos y comunidades que se distribuyen en la cuenca naciente del río Mala; y en cuanto son de economía agro pastoril, siguen necesitando los favores de sus dioses y de los santos patrones, como dioses labradores al igual que ellos.
\end{abstract}

Palabras clave: Pariaqaqa dios andino mayor de Huarochirí.

\begin{abstract}
The southern districts of Huarochiri still preserving the symbolism of Pariaqaqa, as god of water, tied to the characteristics of nusta of their ancestors, which are associated with the existing archaeological sites adjacent to the towns and communities that are distributed in the basin of the nascent Mala River, and because they are agricultural and pastoral economy still needed favors from the gods and their patron saints.
\end{abstract}

Keywords: Pariaqaqa god Andean major of Huarochirí.

\section{Introducción}

La provincia de Huarochirí cuya capital, San Antonio de Matucana, se ubica en los nacientes del río Rímac de la carretera central y a su vez, territorialmente los divide en los distritos del norte y del sur. De los cuales trataremos, a manera de diagnosis, sólo a los distritos de la parte alta de la cuenca o nacientes del río Mala y río Kakachi, conformados por los distritos de: Santa María de Jesús de Huarochirí, Santiago de Anchucaya, Sangallaya, San Lorenzo de Quinti y San Pedro de Huancayre, mientras el distrito de San Juan de Tantaranche que está mas próximo al nevado y Apu Pariaqaqa sólo queda en referencia al igual que la comunidad de Carhuapampa o Qarwapampa. En los cuales entrevistamos a las autoridades locales (Alcaldes) y personas mayores herederos y portadores impulsados por la sabiduría andina, que aún preservan con orgullo la historia cultural que los singulariza y les forja el porvenir con esperanza: desarrollo integral con proyecto alternativo. 
El pueblo de Huarochirí está a 3120 msnm, latitud $12^{\circ} 08^{\prime}$ y longitud $76^{\circ} 0.14^{\prime}$; con la temperatura oscilante de $20^{\circ}$ en diciembre (invierno es la temporada de lluvia) y de $0^{\circ}$ en junio (verano es la temporada sin lluvia) y con el sol eterno en todo el tiempo, según el control meteorológico del lugar.

Este estudio preliminar fue posible gracias al entusiasmo de la colega Gracia Ojeda que fue aceptada y promovida por la Dra. Rosa Vásquez, Alcalde Provincial de Huarochirí, quien con preocupación y actitud resolutiva invitó a la Dirección de nuestra EAP de Antropología de San Marcos, para la participación en el viaje "Conociendo la zona Sur de la provincia de Huarochirí" y al taller "Gestión Productiva Empresarial" (entre el 4 y 8 de abril 2008), haciendo eco al lema de su gestión como "Trabajando Juntos para el Desarrollo de Nuestros Pueblos". Por lo que el Director nos delegó con participación de Alex Azaña, Alonso Burgos y David Gutiérrez, alumnos de antropología que intervinieron con entusiasmo según el plan de trabajo.

Como resultado de este viaje y trabajo de campo preparatorio traducimos el material etnohistórico de Francisco de Ávila (1966) y el procesamiento etnográfico de algunos mitos y relatos, tradiciones y sistema de valores observados y entrevistados de los propios actores sociales; lo que nos permitió adelantar con previa interpretación procesal como patrimonio cultural andina y tradición viva de los pueblos sureños de Huarochirí.

Nuestro reconocimiento a la población y sus autoridades de los distritos sureños, en especial a Francisco Macavilca Alcalde Encargado de Huarochirí, Nilton Saavedra Alcalde de Anchucaya, Marcelino Valencia Alcalde de Sangallaya, Justo Traslaviña Alcalde de Quinti, al señor Alcalde de Huancayre y a la Coordinadora de la Mujer en el concejo Provincial de Huarochirí, Ericka Tardillo y su equipo de trabajo, que han hecho posible nuestro viaje y contacto con la población lugareña y sus autoridades. Asimismo singularizamos nuestro agradecimiento a don Arnaldo Macavilca Tello, quien con mucho desprendimiento y entusiasmo acudió para testimoniarnos la tradición viva de sus ancestros, con el fin de ser recopilado, revalorado y difundido en su sentido histórico cultural, que refuerce el autoestima personal y fortalezca la identidad cultural de sus pueblos.

\section{Distribución espacio cultural de los distritos sureños}

\subsection{Ruta a los distritos sureños de Huarochirí}

A los distritos y pueblos sureños de Huarochirí se acceden por dos actuales rutas carretera trocha: la primera es la ruta Lima por la cuenca de Cieneguilla del río Lurín y desde Antioquia se asciende por la pendiente de los distritos y pueblos de San Juan de Chorrillos, Langa, Lanche y de Iskumarka, caracterizados por ser una zona abrupta y verdoso por sus sistema de riego y de ser un paraviento para los vientos húmedos de la cuenca y del litoral yunga costeña. Y luego de dejar pendientes parajes boscosos con cultivos de frutas de manzana y membrillo, especialmente, franqueamos a la parte alta como territorio rocoso y pedregal inhóspito con escasas espinas cactáceas raquíticas y ávidas, que más pareciera un lugar que ningún dios haya pasado o recordado en su cotidianidad. Con estas impresiones inverosímiles de la conducta religiosa vinculada a la tradición andina nos inquirimos incautamente ¿Qué es lo que tanto disputaron a viva y fuerza los dioses de Huarochirí, con despojos, expulsiones, sanciones y hasta con saldos de guerra a muerte?

Al distrito de Huarochirí llegamos eso de las 8:00 de la noche, saliendo a las 10:00 de la mañana con el "Expreso Pariaqaqa" de los Pérez, entre neblina y llovizna con sobresaltos por los abismos profundos y sobre todo, por la carretera estrecha que el chofer de la ruta hacía malabares de retrocesos en busca de filigranas de espacio para cruzarse con otro bus o 
camión; aunque ya habrían dejado despeñaderos con saldos de muerte en ocasiones anteriores. Pero, lo gratificante a todo ello fue con el nuevo despertar del día en medio de un conjunto de montañas ${ }^{1}$, praderas, quebradas profundas y un cielo azul con astro rey deslumbrante en un espacio paradisíaco; porque la gran verdosidad invernera de abril cubría casi todo el territorio de los distritos sureños de Huarochirí y nada envidiable con de Suiza.

Por esta ruta se llega primero al distrito de Huarochirí y desde aquí se distribuye a los demás distritos, como evocando que Huarochirí fue capital en la reducción colonial y en la república naciente por su ubicación en el camino real de Lima a la región central de los wankas y por su posición central con un clima intermedio $(3120 \mathrm{msnm})$ a diferencia de los demás. Luego, cada cual fue convirtiéndose en Comunidades Campesinas reconocidas y hoy son capitales distritales, como son: desde Huarochirí se va a Santiago de Anchucaya que se ubica en la parte alta del sureste y sus anexos de Llambilla y Lupo; en la parte baja se ubica Sangallaya con sus anexos y estancias de Huancata, Quiripa, Pucllucanchi y Alloca; hacia el este está San Pedro de Huancayre separado por el río Mala e igualmente, San Lorenzo de Quinti está en el encuentro de los ríos Mala y de Kakachi, con sus anexos de Palermo y Huanchaq. Y en la quebrada del río Kakachi ruta al Apu Pariaqaqa se encuentra el distrito de San Juan de Tantaranche, con sus anexos de Wachupampa y Qarwapampa.

Todos estos distritos tiene su contacto tanto por los antiguos caminos y las modernas carreteras trochas carrozables; asimismo, por los medios telefónicos, celulares y algunos con Internet. Igualmente, las principales acequias del sistema de riego descienden paralelo o diagonalmente desde los ríos Mala y Kakachi, que durante la "champería" o "fiesta del agua" motivan para el culto a los dioses andinos y la tarea colectiva comunal para el mantenimiento de las tomas y sistema de canales de los pueblos. Así como los santos patrones no sólo se anteponen a los nombres de los distritos desde su fundación colonial, sino, también constituyen medios de cohesión comunal y formas de articulación de los pueblos circunvecinos y es más, aparecen como iconos representativos.

Y la segunda ruta de retorno o de llegada es por la cuenca de Mala, saliendo de cualquiera de los pueblos se llega a Sangallaya y desde aquí se desciende atravesando los pueblos de Huancata, Quiripa y por Alloca, como último pueblo limítrofe con la provincia vecina del sur; y desde aquí se continua por el territorio de Yauyos, pasando a la localidad de Visca del distrito de Quinocay; luego al fundo de Checas de la familia Ávalos atravesando el sitio arqueológica de Checas que se extiende a ambos lados de la carretera, como nos señala Marcelino Valencia, Alcalde de Sangallaya, con quien compartimos el retorno. Después, pasando el pueblo de Calango se llega a Mala y de aquí rumbo a Lima por la panamericana sur. Esta ruta es más abrigada por descender toda la cuenca de Mala entre los huertos de manzana y membrillo y, aún siendo más lejos en distancia se compensa por el clima y por igual tiempo de viaje a Huarochirí por ahora, por cualquiera de las dos rutas.

\subsection{Pueblos y distritos: Economía y el dominio de los pisos ecológicos de las cuencas}

Dichos distritos, con sus respectivos anexos y comunidades, están ubicados en las inmediaciones de las cuencas de los ríos Saraico y Karachi, como tributarios de la cuenca del río Mala que nace de las alturas de Huarochirí.

La fisiografía es de presentar un territorio accidentado con altos cerros y profundas quebradas con ríos, manantiales y oconales utilizados para la producción con sistemas de

1 Jimmy Contreras nos indica a la montaña "Quintón” (debajo se ubica el pueblo de San Pedro de Huancayre) del lado este (observado desde el pueblo de Huarochirí) y los cerros de Santiago, Qoriwanka, Suni y Choycoto, entre otros, se ubican al lado suroeste. 
riego y grandes espacios de forraje para la ganadería vacuno mejorado (para la leche y derivado) en la parte baja e intermedia y como también en la parte alta (puna y cordillera) para los camélidos y ovinos. Sin embargo, la mayor extensión del territorio es regado por las lluvias en la temporada de invierno y la parte baja con riego; de ahí, Sangallaya y San Lorenzo de Quinti se caracterizan como los distritos que producen maíz (choclo), verduras, frutas (manzana, chirimoya, durazno, palta) y algunos tubérculos como camote y yuca y las verduras (zona qechwa de 2400 a 3000 msnm). Mientras Anchucaya, Huarochirí, Huancayre y Tantaranche son eminentes productores de la papa, habas y arvejas, entre otros, y ocupan la zona intermedia (región suni entre 3000 a $3600 \mathrm{msnm}$, aproximadamente).

Este indica que los distritos sureños de Huarochirí ocuparon milenariamente múltiples posibilidades ecológicas para su desarrollo económico, cultural y social, como "control vertical" (Murra 2002) de los diversos pisos naturales; aunque, desde los sistemas de reducción, comunidades campesinas y su distritalización los delimitaron con territorios inalienables. Sin embargo, los matrimonios exogámicos, el comercio y las migraciones internas siguieron posibilitando la interrelación permanente en distintos niveles y posibilidades hasta hoy. Mientras en tiempos antiguos, el rico potencial archipiélago vertical de Huarochirí constituyó no sólo un territorio ideal compartible por las diversas etnias y ayllus de distinta organización, sino, también posibilitaron a disímiles conquistas y colonizaciones por los dioses y los hombres ávidos de dominio y poder por la región sagrada.

Por ejemplo, en el distrito de San Pedro de Huancayre tienen la ganadería mejorada y criolla para la producción del queso para el mercado, mientras la producción de arvejas, habas, trigo, cebada, frijoles (en la parte baja), ají rocoto y de los tubérculos (papa, mashwa y olluco) son para el autoconsumo.

Justo D. Traslaviña Dávila es el actual Alcalde del distrito de San Lorenzo de Quinti, con profesión en Administración, quien nos señala la preocupación conjunta de las autoridades para el desarrollo respectivo de sus pueblos y distritos. Este distrito estaría conformado por tres anexos: el centro poblado de Santa María de Huanchac, San Bartolomé de Palermo y el anexo de Wachupampa, con una población total de unos 1800 habitantes que tienen por actividad principal la agricultura y la ganadería, produciéndose la papa, cebada, trigo y en los últimos tiempos se ha introducido la fruticultura en la zona baja de Huanchac, especialmente la manzana con buena acogida en el mercado de Lima y otras regiones. Mientras en la ganadería están en proceso de mejoramiento a través de convenios.

\section{Enseñoriamiento del dios Pariaqaqa: Organización del tiempo y la ordenación del espacio según el Manuscrito de Francisco de Ávila}

El texto de Dioses y Hombres de Huarochir ${ }^{2}$ o Ritos y Tradiciones de Huarochir ${ }^{3}$ de Francisco Ávila, muestran la forma de vida y el comportamiento religioso de los distritos sureños, ligados a un antepasado mítico o progenitor común, como una forma de fijar los principios territoriales por derecho de pertenencia y marcar las identidades culturales por legitimidad social, dentro del manejo de la cultura de poder y de la unidad política.

Por lo que, el documento oral inicia graficándonos el modelo de la organización de los dioses y sus estilos de vida, como una suerte de diagramarnos el sistema social y la historia cultural de Huarochirí (Warochiri), como un modelo andino precolombino:

2 Traducción de José M. Arguedas, editado por el Museo Nacional de Historia y el IEP, Lima 1966.

3 Traducción y comentario de Gerald Taylor, editado por el IEP, Lima 1987. 


\subsection{Antiguos dioses}

El tiempo arcano de Warochirí está concebido por el modelo dual de organización, donde los dioses Yanañamka y Tutañamka son los primeros pobladores de la región local; aunque, según la traducción de Arguedas pareciera indicar a una sola divinidad con dos nombres afines.

El reinado de las dos divinidades llega a su fin con la conquista del dios Wallallo Qarwancho (Huallallo Cahuincho) proveniente de la sierra central. Lo que indica el avance de los wankas a la costa central por la parte cisandina, en alianza con los grupos étnicos de los Yauyos.

Wallallo como vencedor no sólo expande su dominio hacia la cuenca cisandina de Lima, sino también impone nuevas tradiciones y formas de control demográfico; asimismo, se considera el creador de una generación ignota. Para ello se establece en Mullococha o Mulluqocha (Laguna de los spondylos), como su principal santuario para recibir tributos de los diversos ayllus o grupos étnicos de la región.

El dios Wallallo está identificado en la categoría principal para su tiempo y uno de sus atributos sería el de transformarse en humano o animal, "brama como león, produciendo truenos; y que arroja rayos, granizo y lluvias" (Tello y Miranda 1923: 512). Es reconocido como el dios con poder de la fertilidad y por eso, entre otras cualidades, es semejante a Pariaqaqa (Paria-Kaka o Pariacaca) y a los actuales Mallkus o Jirka Wampu de Chaclla y Soqta-Qory de San Pedro de Casta.

Wallallo es considerado como el dios guerrero que sostiene "luchas terribles" con sus rivales (Pariaqaqa, Wampu o Makas) y también es el dios muy apasionado porque enamora a las diosas o a las hermosas ñustas ofreciéndoles agua (a los que faltan), semillas (semillero) para las chakras (de maíz, papas, kinua, oka y otras) o plantas ornamentales para los jardines de las doncellas o para la morada de las divinidades.

Wallallo es identificado como el dios de los wankas o guankas (Guaman Poma, 1980) en el panteón andino y habría sido expulsado por los wankas a la región de los Yauyos; luego lucha con Pariaqaqa y también es arrojado de la región de Huarochirí. Aunque llega a enseñorearse en la región de Casta entre la continuas luchas con Wampu y Makas (mallkus vecinos), por lo que hasta hoy, el nombre del dios Wallallo es pronunciado en las ceremonias más secretas por los Waqsas (sacerdotes u oferentes) y es recordado en la simbología de Soqta Kuri, actual Apu o Mallku del pueblo de San Pedro de Casta; quien es relacionado o vinculado con los Qollana de Bolivia o de origen sureño (Arroyo, 2003), a manera de Wallallo que persigue al Yachik (Yachaq: sabio, entendido) para recuperar su órgano generatriz hasta la región del "Kollao", pasando por Wamank'a (Guamanga o Huamanga, donde se enamora de otra ñusta bellísima que acompañó en sus andanzas)(Tello y Miranda 1923).

Por estos sucesos, Wallallo desapareció de la región de Casta y esta ausencia ocasionó mal tiempo: el pueblo fue asolado por enfermedades desconocidas, mala cosecha, por falta de lluvia (y buenas cosechas en la región de Wampu, quien los trasladó el poder de la fertilidad), carencia de árboles de leña y pastos de ganado. Pero cuando Wallallo retornó a Marka Wasi alivió en parte esta desgracia, llevando la lluvia, recuperando algunas plantas y reparando las acequias y lagunas abandonadas. Por eso, Wallallo ya no vive en San Pedro de Casta, sólo retorna cada año portando lluvia para fertilizar las sementeras. Igualmente está sucediendo hoy con Soqta Kuri, quien por malos tratos de su "gente nueva" (la modernidad) estaría para irse a Bolivia y la población estaría preocupada y desconcertada por otros malos tiempos que se avecinan: ¿futuro incierto para la cultura andina por el proceso de la globalización? 
Tello y Miranda (1923) registraron el relato de los mayores casteños (nacidos en el siglo XIX), quienes habían oído de sus mayores que el Año Nuevo andino comenzaba en el mes de junio cristiano, con la aparición de las "cabrillas". En esta fecha habría habido gran concentración en Marka Wasi de las poblaciones aledañas del entorno (Pampa Qocha, Waya Qocha, Kasha, Achin, Waqsa Taka, Opika y otros pueblos o ayllus) y de los peregrinos, precedidos por los Wachik, Yachik, Kuris y Michikuy, quienes bien engalanados y al son de las tinyas y quenas (pinkullos), vendrían a ofrendar a Wallallo en su altar mayor y en la concavidad del Infiernillo ("una zanja profunda"). Incluso, los mayores habrían afirmado que hasta hace poco se "realizaba romería a Marka Wasi, y se solía arrojar dentro del Infiernillo una llamita blanca, y todavía hoy, durante el mes de junio, suben secretamente a la meseta los Yachik y Wachik, para arrojar dentro de la zanja, cuyes, coca, chicha, y zanco" (Ídem: 522).

Asimismo, diríamos hoy, que la fiesta de agua, la limpieza de las acequias o el trabajo festivo es un buen pretexto para recordar, reafirmar y difundir la cultura religiosa andina por los indoblegables y libertarios casteños, quienes, con arraigo y orgullo andino, replicaron, con algunos elementos modernos, la ceremonia ancestral en los meses de setiembre y octubre, donde flamearon las banderas de los siete colores portadas por las cuatro paradas (antiguos ayllus): Karwayuma (de mayor prestigio), Komawpaqcha, Yanapaqcha y Walwalqocha que compitieron en carrera de caballos, limpieza de acequias, en las danzas y takíes de las Waylinas en sus respectivas Paradas, en la laguna central, en las calles y en la plaza de armas del pueblo. Entre los patriarcas (ancianos y sabios) se encuentra el especialista (los Wachik) encargado de ofrendar a los dioses progenitores de "Tayta Yaku" o "Soqta Kuri" (dios del agua), quienes, ataviados de las vistosas y aromáticas flores de kantu y wayagonta ${ }^{4}$, solicitan la gracia de los dioses para un buen año con lluvia y buena cosecha; en Pampaqocha, identificada como la laguna central, es el tinkuy, la unión o el gran encuentro de todas las Paradas, donde, después del rito de propiciación, invocación, aspersión a los dioses del agua y la venia a la cruz (y miran al pueblo), inician el final de la limpieza de la toma y luego, precedido por los mayores (patriarcas) y las autoridades (entre ellas estaban la alcaldesa, subprefecto, presidente de la comunidad y otras), se desarrolla el gran convite o la comida comunal, con todos los comuneros (hombres, mujeres y niños), invitados, turistas y estudiantes de antropología que participamos y compartimos directamente en cada una de las actividades de las jornadas de la fiesta del agua, durante nuestra estadía.

\subsection{Dios Pariaqaqa como restaurador del poder local y regional}

Según el documento oral de Ávila, Wallallo Qarwancho fue derrotado y expulsado por Pariaqaqa a la región de los antis (yunca, selva o zona tropical). Sin embargo, Pariaqaqa surge no sólo para reconquistar el poder perdido por los antiguos dioses; sino, fundamentalmente, para pacificar las guerras fratricidas de los pueblos, enseñar (progreso) a los "purun runas" (bárbaros) y someter o erigir un gobierno y poder central: de la sociedad sin reyes a la sociedad con reyes, de los jefes abusones a un gobierno central o del sistema embrionario a un sistema de Estado.

Al parecer, muchos mitos andinos son recurrentes cuando describen que los pueblos vivían en permanente violencia antes de los incas y en condiciones incivilizadas o purun runas. Luego aparecen los héroes culturales o semidioses encargados de justificar la

4 Estas flores, según testimonian los lugareños, crecían en toda la pradera de Casta y ahora sólo florecen en Marka Wasi y en las altas montañas que son las paqarinas o moradas de los Mallkus o Jirkas, dioses progenitores de las comunidades. 
necesidad de un sistema centralista, mediante la "cultura civilizada" expansiva; aunque, arqueológicamente está casi suficientemente aclarado que el Estado y civilización surgen en el Formativo (Chavín expansivo) y de manera consolidada con carácter burocrático está desde el Horizonte Medio con el Imperio Wari (Isbell, 1990; Anders, 1993).

Luego de la metamorfosis religiosa imperativa de naturalizarse (después de ser padre de Watya Qori se convierte en halcón) vuelve a humanizarse, y este proceso es facultad sólo de los dioses o de los hombres convenidos por sus entes protectores. Pariaqaqa, hecho hombre busca, lucha, vence y persigue a su enemigo Wallallo Qarwancho; para lo cual, asciende a la parte alta llamada "Pariaqaqa", donde se encuentra el templo de su enemigo y esto hace suponer que la región montañosa de Pariaqaqa vinculada a los nevados, lagunas sagradas, abrigos rocosos (paqarinas), manantiales, ríos y quebradas sagradas siempre fueron espacios sagrados o el gran santuario milenario antes de la posesión del Wallallo, incluso este dios, por eso debe haber optado evocar la memoria mítica local de mayor prestigio para su arraigo y/o tratar de suplantarlos. Por lo que aquí se superponen varias y diferentes divinidades en distintos momentos (períodos) para fundamentar, justificar $\mathrm{u}$ oficializar su autoridad y dominio sobre las diversas fronteras étnicas de la región; es decir, la práctica del rito de la magia contamitante es panandina y universal para la institucionalización de la persona y del poder supremo sobre las sociedades con cultura de poder.

Este hecho religioso permitió enseñorearse y recién recorrer pueblos de la región de Warochirí, castigando o sometiendo a la generación anterior o a los mitimaes wankas y yungas de la costa (posesionados en Huayquiusa). Para lo cual, míticamente se convirtió en un peregrino pordiosero para comprobar la lealtad de los súbditos, premiando a los fieles y castigando a los no; asimismo, se transformó en el "granizo amarillo y rojo, arrastró a toda aquella gente hasta el mar sin perdonar a nadie” (Taylor, 1987: 125). Y después de la destrucción o desestructuración del sistema local, para reivindicar su ferocidad inicial a otorgar agua, construye bocatomas, canales de riego para el maíz, ensancha la sequía de los yungas, deseó a la doncella Chuquisuso y luego se desposó.

Dios Kuniraya hace su aparición y su nombre está asociado a Wiraqocha formando un solo nombre, similar a la primera divinidad de Yanañamka Tutañamka. Estas fusiones o dualidades siempre responden al manejo político o actividad religiosa centralista, mediante la fusión o por analogía de sus cualidades y/o funciones similares de los dioses coetáneos para compartir el poder, imponerse o para entronizar y borrar el prestigio del dios local por el conquistador o por el aliado que mide su poder con ventaja y en perspectiva.

En este caso, dios Kuniraya Wiraqocha está relacionado con los artesanos "tejedores de ropa fina", especialistas que gozaban del agrado y favor de la clase gobernante y por consiguiente eran los buenos cultores e invocadores. Sin embargo, inversamente a esta relación, este dios se presenta en la figura de un pobre andrajoso y pordiosero (con su capa y cusma hecho harapos); pero realizando obras: preparando las chakras, reparando los andenes y construyendo canales de riego. Y también, "andaba humillando" a otras divinidades vecinas y enamoraba a las doncellas o a las divinidades locales con astucia, como fue con Kavillaka, quien quedó fecundada por comer la lúcuma con el semen de Kuniraya (convertido en un ave).

Los dioses, así como los hombres, siempre tienen doble figura, de ser sabio/vanidoso, bueno/malo, proveedor/sancionador, orgulloso/taimado, bello/feo, ostentoso/sencillo, andrajoso o reluciente con trajes de oro y plata, para imponerse o enseñorearse en su dominio. Y en sus andanzas van actuando a favor o en contra de uno o de otros dioses, hombres y pueblos; por lo que, al no lograr con Cavillaka, este dios ostentoso violentó a las hijas de Urpay Wachaq (Urpayhuachac), de venganza y, finalmente es expulsado de la región yunga costeña. 
En el capítulo catorce se vuelve a tratar de Kuniraya algo ambiguo, porque describe como dios antiguo, padre de Pariaqaqa y parlamentador con el inka Wayna Kapaq (Huayna Cápac) en el Cusco y le ofrece viajar conjuntamente a Titikaka (antigua paqarina) para mostrar su poder y sabiduría. Esta nueva versión está desordenada a diferencia de la primera, porque hay incongruencia con la lógica de la jerarquía generacional de los dioses o de los gobernantes y hace aparecer a Kuniraya Wiraqocha como un ente que está en todas partes y con todas las generaciones. Por eso Taylor cree que es "muy probable que, en lo tocante al culto de los héroes civilizadores como Cuniraya y todos los otros protagonistas locales que habían sido asimilados a Huiracocha, los conceptos cristianos enseñados en la doctrina hayan contaminado las tradiciones específicas de cada grupo y que el orden jerárquico de los dioses criadores con una organización rápidamente cronológica de dioses padres e hijos, haya introducido cierta confusión ideológica en el cuadro mitológico" (Taylor, 1987: 243). O en su defecto, el mismo padre Ávila busca reinterpretar o recrearlas y le carga mayor significado cristiano, para facilitar la asimilación cristiana por los vencidos, con el esquema trastocado o renovado para justificar la labor pastoral de la iglesia; porque, en los capítulos anteriores ya venía mostrando su preocupación por su posible retiro y el peligro que se cernía sobre la evangelización durante su permanencia. Entonces, cómo justificar la continuidad o la práctica encubierta de la religión andina casi a fines del siglo XVI, con la misma fuerza que antes y quizás con más estrategia; es decir, aceptando a los Santos Patrones con el calendario juliano y luego gregoriano, los oratorios permutados por los santuarios y la aceptación exclusiva de los sacerdotes coadjutores en cada Parroquia y Diócesis; y aún así, los especialistas andinos seguían proveyendo los ritos y mitos a la población, en condiciones cada vez más difíciles y complejas por la desestructuración político-social, económica y cultural del mundo andino.

\subsection{El señorío de Pariaqaqa y la estructuración del poder}

Antes del nacimiento de Pariaqaqa, su hijo Watya Qori (Huatiacuri) anuncia y asiste al lugar (Condorqoto) del nacimiento de su padre. Para ello se dirige desde la ribera del mar hasta la zona cisandina de Warochirí como un personaje pobre y humilde, para luego, con el pretexto de salvar la vida de un posible rico kuraka, consigue desposar a su hija, pelea con su cuñado y logra desestructurar: la familia, alianza local y aún más, lo intimida calificando de ser embustero y no "gran sabio", curandero o "dios".

De esta forma, Tamtañamka es derrocado, dando fin a una jefatura local e iniciándose el dominio con carácter regional, bajo la égida de Pariaqaqa. Este asienta su dominio justificando su origen mítico de nacer como "halcones" de "cinco huevos" y arrasando a los súbditos de su enemigo hasta el mar, en forma de tempestad. Este simbolismo religioso garantiza el modelo del liderazgo y un modo de existencia social, basada en el sistema de parentesco, para legitimar y garantizar la unidad política y el sistema de pertenencias espaciales.

Pariaqaqa le inicia la guerra a Wallallo destruyendo y convirtiendo su santuario en laguna o lo que sería Mullu Qocha, los cinco hermanos enfrentan en el camino de Oqsa Pata (Ocsapata) e incentivan a los pobladores con rebelarse, entre ellos a los grupos étnicos de "Quinti" y los "Checas", con no pagar el tributo o sacrificio a Wallallo y al mismo tiempo, ofreciendo protección y defensa a cuenta de recibir mullu, coca y tiqti (ticti o sanco de sangre de camélidos y no humana) y aún más, pide a la población ser partícipe o testigo de sus triunfos o derrotas, para así reconocer su primacía y aceptar convenientemente ser los súbditos requeridos. Con esa incentivación y arenga guerrera, Pariaqaqa lanza "gran cantidad de agua" a la bola de fuego de Wallallo y también alienta, requiere o amenaza a 
las "Wakas" tutelares de rangos menores de las localidades vecinas, para la efectividad de su triunfo. Aunque ya se proyecta reemplazar la población y crear otra generación, linajes o dioses tutelares que garanticen su avance: "Ami”, Llata" y "Añasi” (según Taylor, podría ser una "filiación establecida entre Pariacaca y los antepasados y dioses étnicos de los ayllus locales" o "fundadores de linajes asimilados a hijos del dios protector regional, el Rayo").

La estrategia de lucha fue que Pariaqaqa atacó de cinco diferentes direcciones con cinco hombres en forma de gran lluvia torrencial de color amarillo y rojo, convertidos en relámpagos, desde la mañana hasta la puesta del sol. Mientras tanto, el Wallallo resistió en forma de gran bola de fuego que alcanzaba hasta el cielo y al ser apagado por Mullu Qocha ("Mullucocha"), huyó a la región de los antis perseguido por el hijo de Pariaqaqa; "Sulluyallap" o "Pariacarco" quedó en la entrada o en la región de Jauja, transformado en un nevado, para evitar el retorno de Wallallo Qarwancho, éste a su vez se habría convertido en el nevado de Waytapallana (actual Apu Wamani mayor de la región Wanka).

Como resultado del triunfo Pariaqaqa sentenció a Wallallo a comer perro por haber recibido sacrificio humano y también a los wankas a tener por su dios y ofrendar el perro; mientras a su esposa Manañamka, considerada como demonio por Francisco de Ávila al igual que los demás Wakas o dioses del mundo andino, también vencida (peleó en forma de fuego) fue "arrojada en dirección del mar" y para que no retorne, Chuqui Wampu (Chuquihuampo) quedó herido cuidando la ruta y en honor a su heroísmo (resultó cojo), el padre Pariaqaqa obligó a "toda la población de estos dos valles" (Sacicaya, Chontay, Chichima, Mama, Huayocalla y Suquiacancha) para que sirvan y tributen con las primicias de sus cosechas de coca y con el sacrificio de una llama estéril; y esta costumbre habrían continuado hasta la fecha del manuscrito, en forma secreta como los otros pueblos que aún conservan y siguen reproduciendo.

\subsection{Formas de relación de Pariaqaqa con Pachakamaq y el comporta- miento de los Ayllus de la Región de Lima}

Es interesante este proceso de socialización del espacio y acercamiento de las formas de relación, entre los yungas y altoandinos de la vertiente occidental: pobladores de los valles de Lima, Lurín y de Cañete con los de la cuenca de Warochirí de la época precolombina y parte de la colonia. El texto nos mostró al inicio la trama social y cultural casi exclusivo de la región de Warochirí, donde aparece Pariaqaqa como el único originario y operador de la región cisandina y a medida que se desliza la función, el comportamiento y la localización de los miembros de la red de su parentesco, resulta una estructura política construida sobre los principios del parentesco y las reglas del matrimonio, para legitimar el espacio logrado y sustentar el poder conseguido.

Luego, el manejo espacial se extiende a través de la figura de Chaupiñamca, como hermana de Pariaqaqa, ocupa con prestigio las cabeceras de Chosica y posee gran movilidad socioespacial. Es una figura prototípica femenina, donde no se ve el machismo patriarcal excluyente, sino actividades, prestigios y relaciones compartidas dentro del juego de las relaciones conflictivas, burlescas y de complementariedades; como viene a ser los distintos nichos ecológicos que se involucran en un sistema ecológico mayor, para competir, desplazar o unificar las fronteras étnicas con patrones y corredores culturales y ecológicas diversos. Es decir, el documento oral nos ilustra con sus propias dificultades y limitaciones históricas, una forma de convivir, organizar y racionalizar la sociedad con el espacio, para seguir haciendo la historia cultural humana, si pretendemos seguir sustentando nuestra especie con sus respectivas particularidades y generalidades. 
Mientras que la waka Lloqllaywankupa (Llocllayhuancupa), en cuanto se identifica como hijo del dios Pachakamaq (Pachacamac) y sobrino de Pariaqaqa (Taylor 1987: 295), es enviado por su padre para proteger a los checas, wanri y los chauti; quienes legitiman y deben su culto. Esto induce a pensar, en que el poder de Pariaqaqa pareciera reducirse sistemáticamente y supeditarse o desaparecer frente al prestigio del dios costeño, con la clara primacía y omnipotencia de Pachakamaq. ¿Obedecerá esta clasificación del poder a la mentalidad centralista o reduccionista del padre Ávila, en relación al centralismo de Lima?, ¿o se deberá al avance inicial y primacía de los yungas sobre los warochiranos?, ¿o es el sistema dual de existencia y de ordenamiento a niveles macroespaciales, entre la figura y hegemonía de Pariaqaqa de la sierra y de Pachakamaq de la costa?; y con la intermediación más dinámica o ambigua de las wakas locales que se ordenan a los primeros. Porque, hoy es frecuente encontrar la distribución espacial andina en la figura y esquema de la jerarquía de los Apu Wamanis (Arroyo 1987, 2004, 2006), desde un nivel local hasta las fronteras regionales, construyendo grupos de parentesco y estructuras sociales y étnicas, en este complicado juego de nuestra modernidad utilitaria e individual.

Porque al hallarse la réplica de la Waka Lloqllawankupa en la chakra de Lantichumpi (mujer) es conducido a la comunidad y al templo de Llaqsa Tambo por su ayllu Alaysatpa. Donde, todos los ayllus, "empezando por los allauca", le rinden honores y culto; y, sin embargo, "Llocllayhuancupa desapareció volviendo a su padre Pachacamac". Por lo que los ayllus de la cisandina peregrinaron donde Pachakamaq para renovarle compromisos y promesas del cumplimiento del culto.

Esto indica el culto de Pachakamaq a través de su hijo Lloqllaywankupa, por los pueblos de Warochirí o por algunos grupos étnicos como mitimaes al servicio de Pariaqaqa o de la avanzada yunga. Asimismo, si “Tamiahuancupa" (Tamiawankupa) es considerado como el sobrino de Pariaqaqa, por asociación se podría considerar como hermano o parentesco con Lloqllaywankupa, así como Pachakamaq con Pariaqaqa; y sus primacías uno del otro podrían responder a los conflictos intergeneracionales, castas o de panacas que construyen su sistema de gobierno y prestigios de poder en sus respectivos espacios de dominio vulnerables; sino cómo explicar la noción de que Pachakamaq tiene pastores de llama en "Suquiahuillca", para los sacrificios oficiales según el turno de cada ayllu o de grupos étnicos altoandinos y lo mismo debió suceder con Pariaqaqa de poseer agricultores o pescadores en la yunga, como principios de intercambio o de reciprocidad social y política.

Este aparente conflicto difuso de los dioses andinos de la cordillera y del litoral podría responder a la confusión de la racionalidad andina o a la descontextualización de los hechos políticos sociales por parte del padre Ávila; porque, luego de mostrarnos una situación de caos o desorganización general del mundo andino, se empeña en resaltar la efectiva cristianización (como orden) de los vencidos en su curato de San Damián. Incluso procura denotar con elementos probatorios de que la población y algunos de los curakas, sacerdotes (waqsas) o la población nativa ya aborrecían o ya no celebraban a sus Wakas por la "voluntad de Dios" o "volvían a Dios" por la "predicación del Señor Doctor de Ávila" (Ídem: 301), como dice: "Si un hombre no hubiese vuelto a Dios con un corazón sincero diciéndoles por este (Llocllayhuancupa) era el demonio, es posible que hubieran seguido con estas costumbres durante mucho tiempo todavía" (Ídem: 303). Por eso, a los oratorios, templos y otros espacios sagrados andinos reemplazaron con las iglesias, capillas y plantaron los cruces, como una forma de justificar el avance de la evangelización, dentro del clima de coerción extraeconómica, represión social, destrucción cultural y exigencia compulsiva del culto más que la conciencia cristiana. 
El comportamiento de las personas, familias, comunidades o grupos étnicos están enmarcados dentro del modelo de organización y juego político de los dioses andinos: clasificaciones, jerarquías y sus respectivas distribuciones espaciales. Quizás por esto fue ininteligible o de imposible acceso para Ávila, introducirse al mundo espiritual de los warochiranos, cuando esta región fue ocupada por sucesivas dinastías (familias, estirpes, linajes, castas, progenies o herencias) desde mucho antes del enseñoramiento de Pariaqaqa. Por eso, los checas muestran en la fiesta de "Macuayunca" sobre su origen, aludiendo a sus héroes fundadores de sus respectivos ayllus.

En la colonia, el Repartimiento de Warochirí estaba conformado por "cinco Huarangas" y el pueblo de Sisicaya, el pueblo de Santiago de Tuna (Tumna) estaba conformado de los "ayllus Satpasca, Allauca, Moxica; Huaracancha, Cacasica; Sulpasca; y Huangri. Parece que estos nombres se hayan conservado, al menos parcialmente, en Tuna y Tupicocha, y quizás en otros lugares de las antiguos tierras de los checa" (Taylor, ídem: 353). Aunque, muchos ayllus están vinculados aún al culto de la Waka o dios Tutayquire (hijo de Pariaqaqa o asimilado al héroe antepasado común) y entre ellos nos precisa el texto a los ayllus "allauca, satpasca, posaquine, muxica, cacasica y sulcpachca yasapa". Asimismo, los checa y los concha atribuyen su origen a las lagunas de Wichikancha y Yarillancha como sus paqarinas arcaicas.

En el caso de los grupos étnicos de los collis, Rostworowski muestra que en el “... tiempo de la conquista Inca, existían dos señoríos principales que ejercían una supremacía o hegemonía sobre un número de pequeños jefes locales. Al norte se extendía el cacicazgo de Collique, ubicado en el valle del Chillón o de Carabaillo y..." (Rostworowski, 1978: 50). El documento oral registra sus orígenes en la región de Warochirí, donde los collis residían en el sitio de Yarutine hasta el arribo de Pariaqaqa como andrajoso, quien al no ser reconocido los castigó con un fuerte viento arremolinado que los arrasó el pueblo: unos murieron y algunos sobrevivieron en el cerro de Carabaillo del valle de Chillón.

Esto indica que la presencia del dios Pariaqaqa significó construcción de un reino y desestructuración de otros, sin embargo, todas las familias, estirpes, linajes, castas, progenies o herencias siempre estuvieron identificados, representados y protegidos por sus respectivas divinidades que se clasificaban o se jerarquizaban por rangos y parentescos para ocupar un espacio reconocido. Esta configuración consagrada del territorio fue similar en la llanura costeña como en la cisandina occidental o en todo el mundo andino.

Una vez logrado el triunfo, como dice en el texto (Taylor, 1987: 161), "Cómo Pariaqaqa, terminando /de vencer a/todos/sus rivales, empezó a organizar su culto" o "Cómo Pariaqaqa, cuando hubo concluido de hacer todo, empezó a dar instrucciones para ser adorado" (Arguedas 1966: 63).

\subsection{Oratorio de Pariaqaqa}

Una vez vencido a Wallallo Qarwancho, los hermanos vencedores retornan al cerro "Pariaqaqa", donde erigen el principal oratorio oficial para su culto y cuidado, como una continuidad de la antigua Paqarina local y regional. En el tiempo de la colonia, como percibe el mismo padre Ávila, los lugareños habrían falseado por preservar el verdadero lugar del oratorio de los PARIAQAQA, indicándoles al nevado Wamayaku (Huamayaco, donde Pariaqaqa descansó al retornar), que se avista desde el cerro "Incacaya", como un lugar peligroso e inaccesible; cuando en realidad, los CUATRO HERMANOS Wakas o dioses, residen en el precipicio de la parte baja, donde habrían construido su residencia o su santuario y habrían dicho: "Aquí he de habitar, que aquí vengan a rendirnos culto" (Arguedas 1966: 101). 
Para ello instruyó a sus Waqsas, incluso el inka o los inkas, también honraron convertidos en otros Waqsas, al conocer su poder y la enorme importancia que constituía para su empresa imperial: mostró su respeto y obediencia y con ello el posible pacto del inka con los señores de Warochirí. Por lo cual, al Apu Pariaqaqa lo encontramos en otros lugares del área andina, con enorme prestigio e importancia local, como en Huancabamba de Piura (Arroyo 2004), Huaraz, Ancash, Huánuco (Astuhuamán 2003); lo que induce a señalar que los inkas y sus aliados (gobernantes y/o los dioses), se encargaron de difundir en su expansión hacia el norte; incluso, si el propio inka dirigió las conquistas, entonces, seguramente participó directamente alguien de los hermanos Pariaqaqa (como héroes culturales) y sus triunfos o su sacrificio permitió metamorfosearse en montañas sagradas en los lugares que se inmoló a nombre del "Inka Rey", como en el caso de Piura, donde el Inka muere y se convierte en el "Cerro Pariaqaqa" y hoy es el "Encanto" mayor local para los afamados curanderos waringueños de Huancabamba.

Incluso, cabe la posibilidad de explicarse la forma de la alianza de los cusqueños con los warochiranos, donde los inkas sabedores del conflicto dado con los wankas y la lucha cruenta con el Wallallo, fue hábilmente manejado para la alianza y esto, a la vez sirvió a ambos para vengarse de los wankas; ya que ambos fueron sojuzgados o agredidos: los wankas conquistaron y sometieron a los Yauyos y Warochirís, asimismo, los wankas en alianza con los Pokras y Chankas (confederación macrorregional) trataron de doblegarlos a los inkas en la batalla sangrienta de "Yawar Pampa". Estos sucesos y procesos sociales de los Estados Regionales e Imperiales del mundo andino dejó una secuela de cicatrices sociales y culturales, por lo que el aparente diálogo de Kuniraya con el "inca Huayna Capac" significaría posibles contactos de los warochirís con los cusqueños, frente al avance avasallador de la Confederación Étnica del centrosur; por lo que, los inkas vencedores reprimieron sangrientamente al posible Estado Triunvirato y consecuentemente, el avance exitoso de los españoles se sustentó en la revitalización de los problemas internos, acelerando la destrucción del Estado Inka, como fue con el apoyo de los huestes wankas. Por lo que más tarde, quizás como venganza o por lo que significaba un peligro latente, la resistencia de Manco Inka arrasa con los wankas, en este caso, los wankas apoyaron a los españoles para la conquista cusqueña (Dumbar 1978); por que la conquista de los españoles al sur y las guerras civiles fueron sustentados por los hombres guerreros de Warochirí, dejándolos casi despoblados.

\section{La estructura étnica y el patrimonio cultural andina como tradición viva de Huarochirí}

\subsection{Composición étnica}

Los 200 ayllus (Matos y otros 1955) distribuidos en sus respectivas parcelas en esta región cisandina fueron reducidos a 39 pueblos por Fernando Dávila Briceño, durante el gobierno del Virrey Fernando de Torres y Portugal, y se funda "Santa María de Jesús de Huarochirí" como capital de la reducción para su respectivo control y ordenamiento, según la ordenanza del Virrey Toledo en 1586. De modo que, muchos pueblos precolombinos quedaron en ruinas arqueológicas y suplantados por otros nuevos pueblos con nombre de los santos y en honor a sus respectivos santos patrones coadjutores como sus sacerdotes cristianos. 
Don Arnaldo Tello Macavilca ${ }^{5}$ de 55 años es uno de los profundos conocedores de la tradición viva y patrimonio cultural de su tierra y como indagación y aproximación suya de su herencia nos narra sobre la estructura étnica que conformó a Huarochirí en tiempos antiguos, asociados al sitio arqueológico de Suni, donde habrían poblado una gran población y entre los últimos y afamados líderes fue Wankaswamán, ya entrados por la invasión hispana. Por lo que, nuestro interlocutor señala como enigma que la región de Huarochirí no habría sido gobernado por los Inkas y como prueba de ello, aduce que: "nosotros no sabemos hablar el quechua, como decir, que somos cholos serranos sin quechua y por eso muchos nos dicen que somos creídos y no queremos hablar". Y a su vez reconoce que ellos hablaban el dialecto kauke, con lo que hasta ahora identifican a los lugares como a: chunkashika, karachuku, shukulla, shumala, Waklashana, aysha, sarayku, etc. Lo cual, según Arnaldo, probaría la independencia de Huarochirí durante el imperio de los Inkas.

Esta visión reforzaría a los fundamentos de los estudiosos que denotaron que el dios Pariaqaqa y la población de Huarochirí fueron los mejores aliados de los Inkas y que compartieron las aventuras de la conquista a las regiones norteñas, como se encuentran muchas montañas sagradas con la denominación de Pariaqaqa (Astuhuamán 1998) o que las ciudades enclaves Inkas fueron convertidas en la montaña de Pariaqaqa, como en Huancabamba, para no ser conquistados por el "rey blanco" (Arroyo 2004). Y por esa alianza política y religiosa gozaron de confianza y de independencia la región de Huarochirí, en cuanto no significaban oposición o peligro para la expansión y hegemonía imperial de los Inkas, preservando su tradición en su integridad y reforzando o ampliando el prestigio del dios Pariaqaqa, como Guaman Poma (1980) dice y registra entre los principales dioses que gozaron de prestigio y de culto estaban Pariaqaqa y Pachakamaq de Lima, Rasuwillka y Qarwarasu de Ayacucho, entre otros de la región de Chinchaysuyo (Arroyo 2006).

Además, nos afirma que los españoles exitosos en la conquista se aprestan dirigirse desde Lima a Huarochirí, y “....aquí se reunieron todos los ayllus, entre ellos estaba de Sangallaya dirigido por la jefa Mamashangay, el jefe de Chaupimaría y hoy es la comunidad campesina de Huarochirí, el jefe Wankaswamán del ayllu de Suni, del ayllu Llambilla con el jefe Guanwarirumo y el ayllu de Lupu dirigido por el señor Achayshicha”. A su vez precisa que dichos jefes siempre se reunían para tomar decisiones para cualquier evento político social y así, conocedores de la venida del corregidor de Lima se reúnen para la resistencia y los esperan en el antiguo camino de herradura que pasa por encima de un gran abismo y por debajo del actual cerro "La Cruz", donde el jefe Wankaswamán asume la dirección total de organizar la defensa, con la consigna de que ningún español debe quedar vivo. De modo que por la retaguardia atacaría el jefe Chaupimaría de Choykoto y de la parte alta con galgadas por los Suni y en el lado Este estaban los de Walashkoto y Guanwarirumo; incluso, nos dice, que si algún español lograra pasar a la quebrada serían consumados por los guerreros de Mamashangay, como la estocada final; y el resultado habría sido el triunfo total como planificaron.

Luego, contradictoria a la condición libertaria de los pueblos sureños de Huarochirí, don Arnaldo afirma que paralelamente, también don "Francisco Inka" de Lawaytambo habría estado movilizando a nivel provincial o regional, para hacer la revolución. Además, aclara y observa que el levantamiento de Wankaswamán fue por defender las tierras de su

5 La historia social y cultural que nos refiere es fruto de la transmisión de sus ancestros y mayores en reiterados momentos de su vida, entre ellos estaría su padre y abuelo don Sixto Macavilca, Benito Tello, Francisco Cuellar, entre, quienes fueron trabajadores y allegados de Julio C. Tello y gozaron de respeto por su sabiduría y responsabilidad para la comunidad. 
pueblo y no por figurar su nombre en la historia social, en cambio Francisco Inka sí habría tenido esa pretensión. Al final, si con la segunda expedición tampoco lograron derrotarlos, después los españoles se impusieron y toman prisionero a todos los jefes de los ayllus; pero no logran apresar a Wankaswamán, porque, como buen estratega logra esquivar hábilmente sin ser apresado. Y como resultado de esta resistencia y conducta de los jefes responsables, nos afirma como anécdota, que los líderes apresados testificaron inculpándose debido a la mala influencia de Wankaswamán y no por que ellos querían; por lo que el jefe español ordenó a sus soldados que los fusilen a todos, porque ya hablaron todo lo que querían saber y por tanto ya no servían para nada. Así habrían matado a los jefes Chaupimaría, Guanwarirumo y Achayshicha.

Frente a la desaparición del líder Wankaswamán, los mayores suponen que con toda su familia se enterraron o desaparecieron en el túnel de la parte alta y otros creen que fue por el túnel de Sangallaya, para no caer en manos de los españoles. Y nadie sabe a donde sale dicha comunicación, aunque los mayores suponen que sale a las ruinas de Pachakamaq y por ahí habrían fugado Wankaswamán y su familia. Por lo que Arnaldo manifiesta que los mayores manejan la hipótesis de que dicho jefe no fue un cobarde fugitivo, sino gran estratega que él logró salvarse con la finalidad de reorganizar su ejército en otro lugar y retornar para liberar su pueblo. Por eso, dice, que habría otro comentario que por la región de Ayacucho o Huancavelica existiría un "pueblito donde todos se apellidan Kaswamán" (¿VilKaswamán?) y cree que podrían ser sus descendientes directos que lograron sobrevivir por allí con la mentalidad de reagrupar más gentes para retomar el poder y liberar su pueblo.

Esta manera de graficarnos podría responder simbólicamente a la expresión subyacente de los huarochiranos sobre las relaciones religiosas sustentadas entre los dioses Pariaqaqa y Pachakamaq, en el sentido del manejo de los símbolos de poder y de las posibilidades ecológicas en el control de los pisos ecológicos, dentro de la racionalidad del sistema de reciprocidad social andina. Además, la figura de la fuga del afamado líder Wankaswamán y sus objetivos representan el ideal andino que nunca fueron sometidos por completo y que existe la esperanza por la verdadera libertad y progreso, como proyecto alternativo de esperanza a la condición actual cuestionada. Evento social homologable al significado de los metonimias andinas descritas en los relatos de las "Aldeas Sumergidas" (Morote 1988), de los "Encantos" de las montañas sagradas (Arroyo 2004, 20006), a los mitos del "Inkarey" (Ossio 1973) o a la idea del "Retorno de las Huacas" (Millones y otros 1990).

Entonces, los españoles, sobre los restos de los ayllus y sus líderes, recién instituyen el dominio en esta región, primero estableciendo como cabeza a "Santa María de Jesús de Huarochirí" por ser la parte central (chaupi) para los demás ayllus, pueblos y lugares hasta hoy. Y asimismo edificaron el pueblo previo planeamiento y ubicación de la plaza, el templo, local de las autoridades, el cementerio y la localización de los ayllus, como nos señala Arnaldo: "El pueblo los dividieron en forma de aspa, la parte central ocuparon los ayllus que bajaron de Suni, la parte Sur a la derecha ocuparon lo que vivían en Mamachangay y la parte izquierda los de Choycoto o de Chaupimaría que hoy día es la comunidad de Huarochirí y la parte Norte ocuparon los de la comunidad de Llambilla y para el lado Este o lado de Chamoko la comunidad de Lupu. Y como prueba de esta distribución es la edificación de sus respectivos locales". Y como otra prueba nos relata los apellidos de las familias representativas identifican a cada barrio, como: los Macavilcas, Qarwavilcas y Garcías son de la comunidad de Huarochirí, Tello y Chukikuri son de Suni, Contreras son de Llambilla, Chukli y Chulan de Lupu. Además, nos asegura que en tiempo antes conservaban la sangre y se identifican rápidamente por sus apellidos, lo que indica 
la preservación de la endogamia; porque nos dice, que "los de Suni no podían casarse con los de Choycoto, mantenían su sangre, sus apellidos y sus tierras cada barrio"; pero, con el paso del tiempo rompieron dicha tradición endogámica y hoy sería generalizada la exogamia; incluso, ahora ya pueden desposarse con cualquier foráneo que arribaran al lugar o traerlos de los lugares de emigración.

Sin embargo, las antiguas clasificaciones de ayllus todavía se preservan a través de las tareas colectivas, en relación a la organización de las comunidades, donde los canales de riego se dividen por kilometraje en relación al lugar y posición de sus tierras, tanto del mantenimiento como para la limpieza. Asimismo, desde la construcción de la carretera en 1940, cada comunidad y pueblos trabajaron su parte y ahora se encargan de su respectivo mantenimiento; aunque la ayuda esporádica del Ministerio de Transportes como de los Alcaldes Provinciales ya viene sustituyendo a las tareas colectivas con el uso de la maquinaria especializada, tanto para el mantenimiento como el ensanche; sin embargo, sigue siendo carretera trocha con riesgo y demora que espera la pronta ampliación para el transporte rápido y adecuado para el despegue del mercado frutícula y potencializar el recurso cultural y el dominio vertical de los pisos ecológicos desde el valle yunga hasta el nevado del Apu Pariaqaqa, para posibilitar el desarrollo del turismo local, regional y nacional.

\subsection{Dioses andinos y las aventuras de Pariaqaqa}

Jimmy Contreras, joven de 22 años, como lugareño nos afirma que el dios principal para la región de Huarochirí es Pariaqaqa y como dios local es Qoriwanka y Chankuya para Huarochirí. Mientras don Gregorio Fernández Marín ${ }^{6}$ (de 70 años) de Anchucaya nos señala que Pariaqaqa es un "tremendo nevado" que en la parte baja existe un "tragadero" donde desaparece todo un río, cantidad de agua que baja para el sector de San Juan de Tantaranche y San Lorenzo de Quinti. Luego nos refiere que Pariaqaqa había luchado con Wichuka, de Santo Domingo de los Olleros, por ser pretenciosa y nos dice que: "Wichuka se había enamorado de Pariaqaqa y él todo sobrado no había cumplido con dar el agua que había ofrecido y a Wichuka la dejó seco. Y como Paraqaqa tiene su cordillera, nevado, río y tiene su agua en abundancia. Por esas razones de la historia, en ese lugar de Wichuka (Santo Domingo) no hay agua. Yo conozco y tienen muy poquísima agua que brota más en este tiempo (abril)".

Por lo que replicamos con el mito que recogimos en Santo Domingo de los Olleros, referida por la señora Escolástica León", quien nos dice: "Vichuka era una mujer muy bella. Eran dos hermanas: Vichuka y Pachakamaq. Dicen que eran dos mujeres y tres varones: Cerro Viejo, Pariaqaqa y Cinco Cerros. Cinco Cerros está al fondo por Kuchowayqo, en la parte alta, y Pariaqaqa está por allá (apunta la dirección como un cerro en punta) y tiene agua; y el Cerro Viejo está para abajo (apunta hacia la costa) y dice que tenía mucho dinero. Vichuka no necesitaba plata (riqueza), no quería plata; ella necesitaba agua para su pueblo. Y sucede que un solo varón estaba enamorado de las dos hermanas y era el Cerro Viejo, porque tenía plata. Y Vichuka decía: no necesito plata, quiero agua. Y como ella era su única enamorada, pero, después interviene su hermana Pachakamaq, como ella quería

6 También nos señala que existe una carretera que sale de Iskumarka directo a Santo Domingo de los Olleros, como la antigua ruta carretera a Lima que dice "Tinaja y Pozo"; y últimamente construyeron la carretera de Langa y Chorrillos por la repartición de Corral Blanco que baja a Matarachi para Buena Vista y de ahí se desciende a Pampachica y de Pampa Grande ya se llega a Manchay. Sería la ruta más cerca arribándose a Lima en menos de 2:30 horas, lo que por la ruta actual se demora más de 8 a 9 horas de viaje

7 Vive en Kushpampa de Santo Domingo y desde aquí es más notoria la montaña sagrada de Vichuka, que observamos con el motivo del relato recogido el 22 de mayo de 2004, fecha que asistimos a la Fiesta del Agua con los alumnos de Arqueología, de práctica en el curso de Antropología General. 
plata, salió gestando. Y Vichuka no sabía nada por que vivía allá arriba (en la sierra), mientras Pachakamaq y el Cierro Viejo vivían allá abajo (en la costa); aunque dice, que Vichuka ya se había dado cuenta al ver que su hermana estaba gestando. Entonces, Vichuka cortó con el Cierro Viejo y en eso, Cinco Cerros conocedor del caso vino a ofrecerle agua; y ella no aceptó diciendo que ya no quería plata ni agua, ni a nadie, y dijo: ¡No necesito agua!, ¡mis olleranos pasaran su vida haciendo su olla! ¡Esta agua no me vale para nada! Diciendo agarro y metió al cantarito de arcilla y con una waraka lo arrojó: la tapita cayó a Buena Vista de Lurín, por eso tiene bastante agua orellana; y el cuerpo cayó a Delicia, por eso está en Pantanos de Chorrillos. Así arrojó por despreció a su enamorado y también quiso matar a su hermana y Pachakamaq se lanzó al mar convirtiéndose en esa isla de rocas hasta hoy".

Y don Gregorio agrega que el "Cinco Cerros" está en San Damián, en la colinda entre Tupiqocha y San Damián que pertenecen a Huarochirí; aunque, después corrigió que los Cinco Cerros pertenecería a Antioquia. También señala que el antiguo "camino inka" pasa por Mesa Redonda y por la altura de Tanta entran a Pachacayo y de ahí se llega a la Oroya y Jauja. Y de Pariaqaqa baja a San Lorenzo por Huanchaq, Quiripa y de Lloca sigue por Vizcas y de Calango a Mala y de ahí se va a Cañete o a Lima.

Según la tradición, escuchó don Arnaldo Tello de Pariaqaqa como a un: "Dios o apu con mucho poder; apu por su agua que vivió siempre enamorado de la princesa de "Chakuya" de Huarochirí y no fue correspondido. Porque Pariaqaqa era un hombre muy especial y como tenía bastante poder se vestía muy simple, pobre y le encantaba desempeñar el papel de mendigo. Y a cambio de su amor le ofreció agua a la princesa Chakuya y le llevó en un cantarito, pero, no le recibió ni le aceptó. Entonces, se fue caminando donde otra princesa llamada "Vichuka" de Santo Domingo de los Olleros, quien tampoco le aceptó; debido a que las chicas eran simpáticas y Pariaqaqa tenía la apariencia de un pordiosero. Pues, quien le iba aceptar así (siguieron las risas). Así, el hombre triste y cabizbajo, fracasado en el amor retornaba y en eso se encuentra con otra doncella llamada Kavillaka tejiendo su manta debajo de la lucma; a quien, también le ofreció su amor de otra manera. Cuando Kavillaka hizo fuerza cayó la fruta lucma bien madura y ella se la comió. Y según la leyenda, ahí estuvo Pariaqaqa y le engendró un hijo y a los nueve meses transcurridos la ñusta se preocupó de gestar sin tener enamorado y menos relación; así llamó a todos lo brujos del lugar para consultar, quienes aconsejaron para que convoque a todos los dioses del lugar; para eso, la criatura ya tendría unos nueve meses, ya gateaba. Así todos los dioses acudieron, porque era simpática y querían estar con ella y llamaban al bebe, ¡ven a mí, a mí! Y sólo el último le atrajo, quien estaba hasta las patas y el bebe se levanta y se abrazó de Pariaqaqa; pero Kavillaka gritó ¡No! ¡Yo estoy de acuerdo con cualquiera, menos con él! Coge al hijo y se va despavorida".

"Entonces, también los demás dioses le increpan y exigen que se presente bien y como tal tuvo hijo que lo afronte y así Pariaqaqa se animó y va en su alcance. En el trayecto se encuentra con diferentes animales, como con la serpiente que estaba bien paradita tipo cobra y le pregunta: ¿Tú le has visto a una mujer con bebe en los brazos? ¡No he visto! Te maldigo, a partir de hoy te arrastrarás por el suelo y por eso dice que la culebra se arrastra. Sigue su trayecto y se encuentra con el zorro, a quien también le pregunta y el señor zorro le contesta que sí a ha visto, pero no ha pasado, sino se regresó. Eres mentiroso, sí el rastro baja por qué dices que retornó; y el zorro se rió. También le dice, te maldigo y a partir de hoy día vivirás perseguido por los hombres, para alimentarte tendrás que robar y por robar te perseguirán hasta matarte. Por eso el zorro vive escondido y para comer tiene que robar. Ahora se encuentra con una palomita, quien le alienta, que lleva distancia y si apuras podrías 
alcanzar; por lo que le dice: Te bendigo palomita a partir de hoy día tú vivirás feliz y tu trinar será lindo en el amanecer y serán fiel con tu pareja, le bendijo y continuó. Y cuando él ve a lo lejos ya llegando a Pachakamaq, la mujer se arroja al mar para no caer en manos de Pariaqaqa y quedó convertida en una isla mayor y el bebe en otra isla pequeñita; ahí están las dos islas frente a Pachakamaq. Por esos casos del destino, también en Lurín sale el agua que llevaba Pariaqaqa, un canal encantado. Así cuentan los mayores y dice ahí están la taya, pasikuna y el ichu. Todo eso existe y ahí sale cantidad de agua y se va al mar".

"Después retornó y nunca más pretendió a ninguna princesa, doncella ni a ninguna ñusta y se fue a la cordillera y como es el dios de las aguas, ahí quedó hasta ahora. Y hay esperanza que algún día volverá a salir, así cuentan los mayores de que algún día volverá y no se sabe cuándo, pero, volverá. Y cuando vuelva ya será otra historia diferente, ya sería la segunda venida de Pariaqaqa".

Este mito de "Pariaqaqa y Kavillaka" tiene toda la estructura del mito de "Kuniraya y Kavillaka" recopilado por Ávila en el siglo XVI, por lo que preguntamos a don Arnaldo si haya tenido alguna lectura o referencia sobre dicho manuscrito traducido y publicado hace bastante tiempo por Arguedas y Taylor. Y su respuesta fue enfática de haber escuchado a sus ancestros tal como nos relató. En todo caso, este mito pareciera ensamblarse con otro relato local algo parcial como es con la "Princesa Chakuya" de Huarochirí y de la "Ñusta Vichuka" de la zona de Santo Domingo de los Olleros; por lo que demanda realizar un análisis estructural y contextual de los mitos en forma integral y asociativa. Además, también insinúa a las actividades cotidianas y de los amoríos propios del dios Pariaqaqa, en tanto se enseñorea en su dominio tiene todo a su alcance, aunque limitado; lo que es similar a las actitudes y cualidades de los actuales Apu Wamanis de la región centro-sur de los andes (Arroyo 1986, 2006), quienes pueden burlarse de las doncellas pastoras o puede desposarla a las mujeres buena mozas de la región, favoreciendo con muchos ganados y riquezas, envidiable por otras mujeres o familias andinas, como compitiendo con la fuerza, destreza y actividad de los jóvenes lugareños.

Y por otra parte, en esta versión encontramos a Pariaqaqa fracasado en el amor por jugar con su poder, al transformarse en un personaje viejo y pordiosero para desear a las doncellas; aunque es reprendido por los otros dioses de la región, que siempre se muestran magnificentes y no como lo que no es; aunque, también es justificable por la conducta varonil de sujetar a sus parejas, a una dura prueba como compromiso de destreza y comprensión para la solidez familiar. Lo que es el deseo ideal y real de las familias andinas como resultado de las experiencias y subjetivaciones en el sistema de valoraciones de las reglas matrimoniales y del sistema de parentesco, dentro del ejercicio dialéctico de la reciprocidad social. Asimismo, algo destacable de este mito es en su desenlace, cuando nos muestra que Pariaqaqa retornó a su centro de origen, de poder, no para quedarse metamorfoseado y conforme, sino retornar para hacer otra historia (¿Andina?). Noción y visión como una negación al presente, como los otros mitos andinos que traducen distintas tramas por la misma diversidad étnica y multiplicidad cultural como nuestro ecosistema andino; aunque, todos con la misma historia motilada o negada, pero seguros con la esperanza de forjar otra sociedad más justa y democrática para todos.

La memoria sobre Pariaqaqa se resguarda en distintos distritos de esta zona con similar estructura y significado al relato de don Arnaldo Tello, aunque varía el nombre de algunos personajes, otros elementos asociativos y el nuevo estilo de relatar, por ejemplo, en la comunidad de Huancayre se narra que Pariaqaqa se enamora de Vichuka y como no le correspondió a sus amoríos por ser andrajoso, tampoco sus padres aceptaban, mediante el truco Pariaqaqa hace caer la manzana y al comer Vichuka quedó encinta. Otros nuevos 
elementos que se utilizan con la presencia negativa de los padres y el uso de la manzana, que pareciera actualizarse por el aspecto del cultivo de esta fruta en las microcuencas de la región para el mercado de Lima y la región, mientras la presencia de la lúkcma es cada vez escasa y poco apreciada por la nueva generación.

Lo mismo se narra para San Lorenzo de Quinti, donde Pariaqaqa aparece enamorándose de una hermosa doncella de Quinti, según el alcalde don Justo Traslaviña, dicha ñusta tampoco aceptó por lo que era feo y haraposo, a pesar de ofrecerle mucha agua para su pueblo; por lo que, dice: "Pariaqaqa se convirtió en una ave y se posó en el hombro de la mujer hasta dejarla encinta"; y luego sigue el drama de su huida hasta convertirse en la isla frente a Pachakamaq. Don Justo, reflexionando relaciona que por estas razones de historia: "Pariaqaqa siempre nos tiene suprimidos del agua, mientras para Yauyos sí tienen agua en abundancia más que acá".

Entre otros relatos, también nos cuentan sobre "Llantoy Toykoña", que significa "El Llanto de Toykoña" o el llanto de una princesa del antiguo pueblo de Huarochirí. Don Arnaldo Tello sigue relatándonos y nos dice: "Antiguamente no existía este pueblo (Huarochirí), estaba en "Wayquiola" a unos $2 \mathrm{Km}$. parte baja. En Wayquiola se celebraba una fiesta de cosecha con grandes invitados y el pueblo. Dicen que el pueblo era todo cercado con un portón grande llamado zaguán para la entrada y salida, donde se controlaba el ingreso de los invitados. Todos los invitados pasaban hasta que llegó Pariaqaqa, como de costumbre, disfrazado de mendigo y los encargados de la puerta no permitieron pasar al ver todo pordiosero, pese a que Pariaqaqa exigía ser otro invitado. Y, entre otras señoras wachakamas (las chicheras), sólo la "Wachakama Toykoña" le invitó la chicha de compasión, cuando todos disfrutaban del banquete en que nada faltaba. Lo malo de Pariaqaqa es de identificarse como una simple persona y no como que es dios, sino lo atenderían mejor. Entonces, Pariaqaqa le dice: Toykoña, tú eres la única que te has compadecido de mí y el resto pasan con olorosas viandas y nadie se recuerda de mí; pues te digo, que te alistes y mañana temprano te vas arriba al cerro Matawa. Yo voy enviar un castigo para que toda esta gente se recuerde. Tú sales y te vas, escuches lo que escuches no voltees para nada; serás la única que se salve, no te olvides. Así, Toykoña continuó en la fiesta y en la mañana siguiente consultó a su familia sobre el anuncio del anciano. Algunos pensaron en el engaño, mientras una hermana aceptó la posibilidad y sugirió que cumpla lo indicado. Así se alisto y cargando sus cosas en kalashmanta (quipe) se fue y cuando estaba subiendo el cerro empezó a nublarse, mas arriba empezó los rayos y truenos y después siguió un gran ruido con lluvia torrencial y al llegar al lugar de Chikri no soportó y volteó a ver que pasaba con su pueblo y en ese instante miró que muchos wayqos (aluviones) sepultaban y arrazaba Wayquiola; y también, por ver todo eso o por desobedecer, la señora quedó convertida en piedra. Llegué visitar ese lugar y vi que es una piedra chata que tiene dos agujeros por donde brota el agua. Dicen que esos ojos y el agua es el llanto de Toykoña. Esa piedra existe hoy en día en Chikri, incluso, el ex Alcalde de ahí sacó el agua para el pueblo de Huarochirí'".

Este relato pertenece al mito clásico de las “aldeas sumergidas” del mundo andino, que se caracterizan por una sanción moralizadora para preservar no sólo el sistema de solidaridad social, sino, también exige el respeto y atención debida a los ancianos o a los padres, que en última instancia simboliza el culto ancestral o devoción a los dioses; porque eso significa experiencia y creatividad de las generaciones con prosecución y resguardo cultural, mientras los dioses crean y conducen a un pueblo, pero, si se convierten en avasalladores exigen los dividendos eternos a toda costa de los otros y si son dioses vencidos, tienen dos únicas alternativas: en cuanto exigen a la sumisión es porque se acomodaron en la estructura 
de poder y propician el pesimismo a todo intento; sino, enseñará a resistir con ventaja y cuando ya es tiempo conducirá hasta la liberación de su creación, pues son dioses que buscan trascender o hacer la historia social y cultural de los pueblos. No hay otra condición de existencia de los dioses, por lo que, la historia mítica o religiosa de los pueblos o de las civilizaciones están cargadas del trama de los dioses, donde, el dios vencedor es vengativo y se ufana en enseñorease o sancionar al mas débil y con los fuertes se alían o transan con astucia y ventaja para vivir o beber de su propia creación (pueblo).

Si bien es cierto que para hoy aparece Pariaqaqa en la apariencia de un dios mítico o algo alejado en el tiempo, también es cierto que sigue siendo como el dios que controla el agua desde el nevado que lleva su propio epónimo, ya sea otorgando más agua o sancionando con la sequía para la mala cosecha de la región, como también beneficiando la fecundidad de las alpacas ${ }^{8}$ de los pastores alto andinos de la región Huarochirí; por lo que a sus homólogos Apus Waytapallana, Wamanrasu, Rasuwillka y Qarwarasu de la sierra centro sur los evocan (tributados con los pagapus) en la fiesta del ganado o en la fiesta del agua (Arroyo 2006). Mientras para Huarochirí ofrendan a Wankaswamán ${ }^{9}$ como el Apu principal y sobre todo la comunidad de Suni que está más próximo rinde culto el 3 de mayo y según don Arnaldo Tello, es la "fiesta de las cruces" y precisamente en ese cerro arqueológico está plantada una cruz, porque son ruinas donde están sus ancestros para los dos pueblos; y asimismo, en todas las bocatomas están las cruces, que son los lugares sagrados que desde tiempos inmemoriales constituyeron receptáculos de las ofrendas ${ }^{10}$ para los dioses del agua. Mientras el Apu Quintón es para San Pedro de Huancayre.

Muchos de los mitos están asociados y/o describiendo a los sitios arqueológicos que son considerados como la "casa de los gentiles" sobre las montañas sagradas, en relación a este significado, don Arnaldo Tello, desde la parte alta del pueblo de Huarochirí, nos indica hacia el lado Suroeste donde se ubica las ruinas de Choykoto, como la antigua civilización dirigida por el gobernante Chaupimaría, sigue al lado Este el sitio y montaña de Wankaswamán y en cuya cima, hoy aparece una cruz como indicando la presencia cristiana o como exorcizando los "sitios paganos". Asimismo, entre estas dos montañas aparece otro cerro más al fondo y se le recuerda como el aposento de la princesa de Chakuya, a donde visitaba el dios Pariaqaqa para enamorarla. Mientras en la parte más alta del cerro del lado Norte del pueblo de Huarochirí se ubica las ruinas, montaña sagrada o el "Apu Qoriwanka" identificado como uno de los descendientes de los Wankas de Huancayo o denotando la presencia y dominio de Wallallo Qarwancho y la guerra con Pariaqaqa. Y hacia el Noreste aparece el "Cerro de Warirumo" o las ruinas que pertenecen al territorio de la comunidad alta de Llambilla; y en la misma dirección aparece las ruinas de Walashkoto cuyo jefe habría sido Achayshisha.

8 También hacen casar a los jóvenes mejores muestras y en la parte baja el matrimonio es de los ovejas en el día de San Juan del 24 de junio ("Patrón del ganado"), siempre propiciando la reproducción al colocar las cintas y depositar la ofrenda en el mismo corral de los ganados, donde colocan todas las antiguas cintas, la punta de cola que se corta y acompañado por la mama coca, cigarro y el pisco y se coloca bajo rezos y danzas con grandes guapidos; siempre recordando y evocando a los antiguos ganaderos forjadores, a los "awelos" y a los Apus de la localidad y de la región. También es de recordar a los pastores con su "ricachico" (es la wallqa) preparados con las frutas, bizcochos y panes.

9 Este nombre es quechua ayacuchana que significa "Halcón de los Wankas" y al parecer son sitios arqueológicas de los wankas durante la hegemonía del dios Wallallo Qarwancho en la región de Huarochirí antes del nacimiento y fundamentación del dios Pariaqaqa, así como también hay otras ruinas denominados en kauke. Por lo que precisa realizar estudios etnográficos y arqueológicos más sistemáticos para definir su posición y ubicación.

10 Todavía ahí se arrojan la cancha, charki (chalón) y el queso, las frutas y el trago o pisco en los manantiales de donde emergen el agua, con rezos y oraciones, para haya más agua para la siembra, según nos testimonio don Arnaldo Tello, como rito de propiciación del agua, común en toda esta región. 
Y hacia el lado Sureste aparece otra montaña alta conocida como el cerro de San Lorenzo, como apu del pueblo de San Lorenzo de Quinti que se encuentra en la parte baja o quebrada, y en cuya cima estarían los sitios arqueológicos de Llacuaz y Pará; y luego siguen otra cadena de montañas que pertenecen a los anexos de San Bartolomé de Palermo y Santa María de Huanchac en los confines con el territorio de la provincia de Yauyos, para conformar el abra o la cuenca de Mala y del río Mala que nace de la laguna de Chumpiqocha que desciende al territorio yunga costeña de Pachakamaq. Y quizás por eso, como resguardando la memoria de la historia religiosa andina precolombina y la cristiana desde la colonia, en la frontis de la puerta del lado Suroeste del templo de San Lorenzo de Quinti aparecen dos figuras religiosas: primero está la imagen del "dios sol” justamente encima inmediato de la puerta y en la parte superior siguiente está la imagen de San Lorenzo, como denotando simbólicamente el culto o memoria colectiva paralela de dos figuras religiosas que pertenecen a dos distintas civilizaciones en un mismo territorio.

Igualmente las ruinas de Sangallaya, ubicada en la parte baja de Huarochirí y en el lado Norte del mismo pueblo y distrito, fue el pueblo que le precedió bajo el gobierno de la jefa de Shangal, la sucedió a la muerte de su esposo bajo consentimiento de su pueblo y por la misma razón le habrían nombrado como "Mamashangal".

Los curanderos. En Anchucaya habían muy buenos curanderos y entre ellos nos señala al finado don Apolinario Alán Pampavilca (de unos 90 años murió hace 5 años) y don Ladislao Alán Malvín era otro buen curandero a base de yerbas y con jobeos o pasaba con el cuy, gato, perro, gallina o con la vizcacha; incluso, a cualquier accidentado los aplicaba emplasto de culebra o el aceite de lagarto. Además nos afirman que dichos curanderos o curiosos pactaban con los Apus y todo lo sabía a través de ellos, lo que indica que los antiguos waksas hoy operan sólo a nivel de los curanderos.

\subsection{La champería y el culto a los dioses}

Se celebra en todo el mes de mayo, donde cada canal tiene su presidencia; siendo el canal más antiguo el de "Chaullari", "pueblo viejo", "Totorachi”, "Wanchaka", "Kunulaya y "Malingula", entre otros canales del sistema de riego de Santiago de Anchucaya. Igualmente celebran en el manantial "Masyaku", vital para su sector. Y entre los productos principales están la papa, oca, mashwa, las habas y la cebada sólo para el autoconsumo. Mientras la ganadería vacuno es vital para el mercado local y regional de Lima y fuente de ingreso familiar y en la parte alta están los ovinos y camélidos en las comunidades de Primo y Sunicica.

La represa de Chumpiqocha es la que les da vida a Santiago de Anchucaya y de ahí tienen varios canales para el sustento de la agricultura y ganadería, precisamente de ahí nace el río Mala y también de la cordillera de Wachín y de ahí ya colinda con zona de San Mateo de Huancho para el Rímac.

En el distrito de San Pedro de Huancayre la "limpia cequia" se realiza con la faena citada a los comuneros, quienes asisten con entusiasmo a la limpieza de la "acequia que da vida al pueblo" y cuando está concluida todos acuden a la toma para la "sacada de agua", con banda de músicos, adornadas con guirnaldas de las flores del campo y con las pajas en los sombreros que llegan a los cuatro estancos (reservorios) entre cohetes y guapidos para esperar la llegada del agua y mientras tanto, todos los trabajadores bajan en carrera para la "chaqtada" o el "gran banquete" en honor a los dioses, destacándose el queso y la papa con ají especial, camote, mashwa, oqa (oca), las habas, la kancha y el cuy o el charqui (chalón de carne), como la comida típica de la champería preparada por las simpáticas lugareñas y 
servidas sobre los vistosos colores de las $\operatorname{mantas}^{11} \mathrm{y}$ manteles decoradas a mano (tejido), en la misma plaza del pueblo de Huancayre; y precisamente en este convite cada parcialidad muestran competitivamente sus mejores muestras de artesanía y gastronomía. Después del almuerzo ritual, concluyen con la danza ritual de "china-china" y el salto ritual de la fogata augurando un nuevo año próspero.

\subsection{Los santos patrones $y$ las fiestas santorales}

Margarita Sedan, regidora de Santiago de Anchucaya, nos señala que el 25 de julio festejan al santo patrón del pueblo a cargo del síndico de la iglesia y la señora Inocente Macavilca Pampavilca es la 2da. Mayordoma para el segundo día de fiesta, del 27 es la señora Mirta Zavala Rivera y del 28 está a cargo de don Waldir Saavedra. Se festeja con la danza de los "Singas" (con vestido de pura plata bailan el rey y la reina) en el día central. También se celebran los carnavales y luego cada comunidad festeja, como los Yungasa Primo festejan a Santa Isabel el 2 de julio, de Rímac festejan en diciembre a la Virgen, Sunicica en setiembre y la parcialidad de Julcatampo el 24 de junio a San Juan Bautista; mientras en Llamayco es 1ero de enero en homenaje al "Niño de Circuncisión".

Don Arnaldo Tello nos manifiesta que en esta región, el pueblo que se distingue de los demás es la comunidad de Llambilla, por organizar fiesta más grande del 15 de agosto a la Virgen de la Asunción con la danza de los "negritos" y también a Santa Rosa de Lima el 30 de agosto con la danza de los "ingas". Estas dos santas se convirtieron en signos de competencia y prestigio para los lugareños, quienes se afaman con organizar mejor que el otro mayordomo. A estas fiestas santorales se adicionaron las ferias pecuarias regionales de Huarochirí (el 15 y 30 de agosto) y dicen que en la exposición de competencia siempre la familia Macavilca de Huarochirí se sobrepone con presentar a los ganados vacunos lecheras mejoradas de pura sangre y desde esta familia se viene ampliándose al resto de las familias, comunidades y pueblos, reemplazando a las criollas que gradualmente viene reduciéndose. En cuanto a las ferias locales viene ampliándose a Santiago de Anchucaya, San Pedro de Huancayre y San Lorenzo de Quinti.

También la comunidad de Huancayre está formada de tres parcialidades: Yanavilka, Yaneq y Corpus; los cuales se aprecian en la organización competitiva del santo patrón de San Pedro el 29 de junio. En esta principal fiesta santoral todavía subsiste la tradición de los "Cajueleros" que consiste en que hay personas comprometidas de llevar la imagen de San Pedro como una promesa y el último día de la fiesta de San Pedro, de todas las parcialidades de la comunidades acuden a la celebración con su respectivo "cajuelero" o el tesorero portando mucho dinero en los mejores caballos bien ataviados (con rienda y montura chapeada de plata) para sobrepujar a sus contrincantes y llevárselo como ganador a la imagen para su localidad hasta el siguiente año; por lo que, como nos dice el señor alcalde del lugar: "Antes se pagaba para hacer la fiesta del santo patrón y ahora ni pagado aceptan ser mayordomo, incluso, antes se usaba la retama de chamizo y ahora sólo con la paja del trigo se hace la fogata". Y, entre otras fiestas representativas, está la "Fiesta de las Cruces" y con ese motivo bajan la cruz mayor de la afamada montaña sagrada del cerro Quintón, seguido de otras cruces menores de Takle y de Angaspongo que está cerca al río. Asimismo se continúa con la tradición de la fiesta de "Los Kurkuchas" en los carnavales de febrero o marzo, que consiste en el concurso de bailes en competencia con los pueblos vecinos.

11 En Huancayre observamos el taller de artesanía de la señora Modesta Ignacio Carhuavilca y esposo, que elaboran mantas, alforjas, pañolones y ponchos para la venta en la localidad y/o ferias de su región. El esposo usa el telar de pedal y la esposa la kallwa así como el telar de cintura. 
San Lorenzo de Quinti es otra comunidad antigua y por razones de fundación rinden culto a su santo patrón el 10 de agosto, como una fiesta más representativa del distrito y asimismo, cada comunidad o anexo festejan a sus respectivos santos como a San Bartolomé el 24 de setiembre,

\subsection{Sitios arqueológicos: Antiguos pueblos y ruta de los dioses}

Según don Gregorio, en Santiago de Anchucaya conocen a las ruinas como la "casa de los gentiles" y entre ellas nos señala la de Lachoq, Punta y la chullpas del cerro San Pedro y aduce que la gente no entra por temor a enfermarlos; aunque algunos profesores foráneos lograron huaquear por la referencia de los alumnos, obteniendo tejidos y vasijas para el museo de la escuela. Igualmente en el gran abrigo rocoso de Tupayquiri habría pintura y estructuras que divide a la cueva como una casa, así como hay dibujos del sol y la luna en una laja de piedra grande en su otro terreno.

José Joaquín, de 26 años, es natural de San Pedro de Huancayre, nos señala a tres principales sitios arqueológicos para su distrito: Cuchicuchi (Chancho-chancho) estaría a $3 \mathrm{~km}$ y muestra las estructuras de vivienda y plaza circular, del Río Seco (más arriba del primer sitio) hay un cementerio con pequeñas estructuras adosadas a un abrigo rocoso (cueva) conteniendo los restos humanos con muestras de ofrenda de los huesecillos de cuy, honda (waraka), plumas de colores y metales. También nos señala, José, cuando abrieron canales para el desagüe en el mismo pueblo encontraron vasijas de buena factura, silbato, plato y cuchara de cerámica, los cuales habrían sido recogidos por el actual gobernador; y estos hallazgos indican que el pueblo de Huancayre se edificó sobre los escombros de un antiguo pueblo. Además, refiere de las estructuras arquitectónicas en las alturas de San Juan y de la antigua acequia que sale de la laguna y se dirige a las ruinas de Cuchicuchi.

Entre otros recursos arqueológicos más destacables está la "ruta sagrada del dios Pariaqaqa" hacia la región yunga costeña de Lima antigua o Pachakamaq o viceversa, delineados y edificados por los antiguos ingenieros o arquitectos, registrados por los cronistas aventureros y estudiado por los actuales arqueólogos que buscan comprender y explicar la historia social y cultural de su tiempo, no sólo con el sentido de rescatar y revalorar, sino, también de forjarlos con sentido de pertenencia e identidad que los reafirme el autoestima a los propios actores herederos que se debaten entre lo propio y lo foráneo, como efectos de la agresividad de nuestra cultura moderna urbana alienante y excluyente. Desde esta perspectiva, don Arnaldo Tello nos precisa dicha ruta que siguieron y enseñaron sus ancestros ó haya recorrido parte de ella, como que: "El camino viene de Pariaqaqa por Qarwapampa, Tantas, San Juan de Tantaranche y de ahí pasa a San Pedro de Huancaya para cruzar el río Chakway, sube y cruza el pueblo de Huarochirí por la calle real, así se llamaba antiguamente, y continua el camino por donde está el actual Centro de Salud, para proseguir por Kanllaka, Makachaya, Pakura, Quiswarpuquio, Sawachili, Cruz de Paso, Pakumanta, Iskumarka, Corral Blanco, Espinal, Piedra Viuda, Buena Vista, Tinaja y por Barranco Grande llega a Manchay y enrumbar hacia Pachakamaq o a Lima. Existe ese camino por donde trajinaron los mayores y desde Pariaqaqa sigue por Lloqllapampa rumbo a Jauja y Huancayo"; incluso, esta ruta fue de intenso trajín por los huestes del grupo armado de "Sendero Luminoso" y en la década del noventa llegaron atacar sólo al pueblo de San Lorenzo de Quinti, mientras los miembros del resguardo policial se encontraban en la fiesta del distrito de Huarochirí.

Así como el camino conduce a los pueblos y a la residencia de los dioses o de los hombres, también hay "canales sagrados" o encantados que conducen el agua a las chakras de cultivo y en cuanto están vinculados con la obra de los dioses, también tienen 
su forma de manifestarse y de asistir a la población. En este sentido, don Arnaldo Tello nos ilustra como algo real y serio con el relato siguiente: "Según decían, el canal encantado es de Pariaqaqa, por donde iba, iba encantando el canal de agua. Existe ese canal allá arriba en Kantaka (a unos $8 \mathrm{Km}$.), donde vivían los pastores don Pedro Contreras Vilca y su esposa doña Victoria. Mientras la esposa salía con el ganado hilando la puchka, el esposo quedaba en el corral tejiendo alforja y kalashmanta y siempre le vencía el sueño eso de las dos o tres de la tarde; despertaba y seguía tejiendo. Así era su vida cotidiana hasta que un buen día escuchó unos ruidos que parecía avión y sin hacer caso siguió tejiendo, pero cuando era intenso salió afuera a mirar y el ruido desaparecía y descubre que el ruido procedía de la choza y sacando su cama levantó una laja central y descubre como un río de agua que pasaba en cantidad y el hombre quedó sorprendido y al ver que salía su vapor como humo volvió a tapar. Y cuando en la tarde retornó su esposa le dijo: Victoria nos vamos, esta casa no vale, seguro por eso estaremos enfermos y mucho sueño me da, porque, por aquí pasa un río de agua y nosotros durmiendo sobre ese rió. Y la señora al revisar no encontró nada y le reprochó; y al final decidieron mudar la choza a otra parte del corral. Sucede que el señor había visto un canal encantado y al poco tiempo se enfermó grave que ni el médico pude salvar. Murió enflaqueciendo, pálido, hueso y pellejo, hace unos 15 años. Así desapareció el agua y los mayores comentaban de que el hombre perdió su suerte, lo que hubiera hecho es de colocar la misma laja de compuerta, para que el agua brote y si el agua brotaba, hoy hubiéramos estado en maravillas, porque toda esa zona carecemos de agua. Todo es pasto seco. Así se perdió la gran oportunidad. Y si dice que era agua de Pariaqaqa es porque por ahí transitaba Pariaqaqa para ir donde la Vichuka”.

Entre otros antiguos pueblos abandonados, como "casa de los abuelos", existe uno que no deja de ser evocado como una forma de ponderar un modelo ideal del pasado y siempre refrescar la memoria colectiva de las generaciones como un referente y un reto, como reprochándose: "si ayer vivieron mejor y por qué no hoy". Don Arnaldo, entre otros relatos nos narra sobre lo que fue el "Pueblo de Mariatana": "Ese pueblo queda a unos $20 \mathrm{Km}$. hacia el suroeste de aquí y es cuando una tarde me encuentro con un viejito y pregunté el por qué dicen "'Cura"” a los de Mariatana, me contó la siguiente historia. Antiguamente no existía este pueblo, sino estaba a unos $5 \mathrm{Km}$. mas abajo; ahí vivíamos como en un paraíso, teníamos un manantial que brotaba agua en gran cantidad y toda tierra que regaba era fértil, si sembrabas una papa cosechabas medio costal, sembrabas una planta de fruta y cosechabas un costal de manzana o naranja. Todo era en cantidad, pero teníamos que pagar a un príncipe y el pago consistía en que todos los años teníamos que entregar un bebe y con eso ya estaba asegurado la cosecha. Y la ley del pueblo era que toda persona que se casaba, el primer hijo ofrendaba al príncipe. Así entregaban año tras año y ya era una costumbre del pueblo. Hasta que una oportunidad no hubo matrimonio, entonces, al matrimonio del año pasado exigieron que vuelva a entregar su bebé y la pareja no aceptó, justificando que ya entregó su primer bebé, porque sino, si el próximo año no hay matrimonio, también me exigirán a entregar mi tercer bebé y así no puede ser. Así se revelaron, pero las autoridades y la población exigían y cuando con desesperación se encontraban llegó al pueblo un padrecito (sacerdote) que anunció, que todos aquellos quieran comulgar mañana tenían tiempo de confesar en la noche. Así la pareja fue a confesarse y pedirle ayuda para que interceda con las autoridades para no seguir sacrificando sus hijos y el padre sorprendido exclamó cómo era posible que sigan rindiendo culto al "Satanás". Y el padre todo furioso se mandó un sermón en la misa amonestando que no era posible que sigan con el "culto al diablo" y amenazó que todos irían al sacrificio. Entonces, las autoridades del pueblo pidieron al sacerdote dar alguna solución. Y el padre se comprometió con ir a la cueva a media noche, 
donde había una piedra cuadrada y ahí tendían baytillas y mantas de la mejor (calidad) que había y ahí depositaban a los bebes. Del fondo de la cueva, primero salía un ruido y luego el humo negro y entre el humo aparecía el príncipe: un caballero muy elegante y simpático, quien cogía el bebé y entre esa nube negra desaparecía. Y toda la gente aclamaban ¡ya recibió, ya recibió!; con alegría de que ese año tendrían cosecha en abundancia y efectivamente recibían en abundancia. Entonces, el padre se propuso hacer la misa a media noche y la gente esperaba con incertidumbre, susurrando ¡que al padre se lo lleve! Y dicen, por cierto el padre inició la misa todo tembloroso y empezó el ruido, pero ya no salió el humo, sino un ave grande, como el cóndor o algo así, salió volando rumbo al Sur. Luego, nuevamente con otro ruido salió un murciélago gigante con horribles chillidos. Y cuando ya no hubo otro ruido, el padre dijo: Hermanos míos, salvaos, bienvenidos; luego a todos distribuyó la ostia y los bendijo. Así festejaron todos hasta el amanecer en son de la banda musical del pueblo y cuando retornan al pueblo, a las seis de la mañana, entre pisco y nazca, para la gran sorpresa ya no había el pueblo. Sólo quedaban grietas, como cuando pasa un aluvión se lo lleva todo. Solamente había quedado la iglesia, como una isla, en medio de un peñón y también desapareció dicho manantial que servía para el riego. Y la población habría exclamado: cómo era posible quedarse sin nada, hemos perdido todo. No hay chakras, no hay ganados, no hay nada. Y alguien gritó, iquién es el culpable! y todos contestaron que era el ¡Cura! ¡Matemos al cura! Apresaron al cura para ejecutarlos, pero salió la idea general de que matar al cura sería un grave pecado. Entonces, acordaron encerrarlos en su iglesia y los tapiaron para que no escape, amarrados los pies y manos; y toda la población armados de palos y piedras sitiaron al templo y al tercer día escuchan el ruido y alguien divisa que el cura escapaba y cuando dio alarma, todos persiguieron y al verse rodeado sólo le quedó subir a la piedra más alta donde se arrodilló pidiendo clemencia: ¡Dios mío aquí estoy! con la mirada al cielo y las manos extendidas y en ese momento quedó convertido en piedra. Así, el viejito Francisco Pérez me dice: hijito, mañana temprano visitas y verás a la piedra como un monumento. Por cierto existe esa piedra".

En eso, David ${ }^{12}$ que escuchaba con atención preguntó de inmediato: ¿usted ha visto? Y don Arnaldo respondió: “Tuve miedo ¿que tal si voy y también quedo convertido en piedra?” Todos quedamos en risas, aunque con la cabeza desconcierta por algo inaudito para nuestro tiempo. Sin embargo, nos precisó que dicho lugar misterioso existe y se ubica en el sector de Mariatana, pueblo en ruinas que abandonaron para fundar el actual pueblo de Huarochirí.

Al margen de que existió o no dicha cueva, personaje diabólico o el cura y su conversión; lo cierto es, para la población con tradición es un hecho social y se ha dado tal como registra la memoria colectiva con sus respectivas adiciones u omisiones, como parte de la recreación por el proceso histórico social. Antropológicamente es fruto de un hecho social y cultural que tiene significado simbólico y por ahora podemos señalar entre otros, dos aspectos: primero, este relato ata la oposición de la tradición andina de origen precolombina con la tradición cristiana de origen colonial, a manera de conquista y evangelización del mundo vencido, en la figura del "príncipe endemoniado" y el "cura evangelizador" frente a un pueblo eminentemente agrario que hasta hoy la preocupación no ha dejado por la productividad de sus tierras y de sus ganados, siempre con la incertidumbre del mal tiempo que conduce a la mala cosecha y el buen tiempo con la buena cosecha o abundancia y cosmogónicamente, todo eso dependía de la buena relación con los dioses:

12 David Rodríguez Ruiz, alumno de Antropología, participó en el viaje a los distritos sureños de Huarochirí y fue el responsable de recopilar los mitos y otros relatos orales, por lo que, con iniciativa y dedicación logró la entrevista con don Arnaldo Tello, quien con entusiasmo y diligencia acudió a la casa del señor Alcalde de Huarochirí para narrarnos este relato y otras tradiciones, como buen heredero preocupado en rescatar y transmitir la cultura de su pueblo. 
los dioses andinos siempre demandaron su comida como intercambio de dones, el pagapu o la ofrenda en productos, como divinidades fecundizadores y fertilizadores del mundo; mientras el Dios cristiano dejó sus primeras expresiones en su tierra natal (de recibir en ofrendas y sacrificios) y al emigrar prefirió recibir o demandar ya en tributos o en algo "contante y sonante" (dinero o metales preciosos) por la exigencia del mercado y el poder colonial, como una fuerza abstracta e impersonal. Y segundo, por concepto y por estrategia política económica, la administración colonial estableció el sistema de reducciones en todo su dominio y para darle un sentido religioso cristiano, se practicó la exorcización de los pueblos viejos nativos y se reemplazó con el rito de fundación de los nuevos pueblos cristianos a imagen y semejanza al modelo ideal cristiano y modelo real colonial hispana.

El caso de "Shinshu en Choykoto"13 o Inocencio Macavilca, pariente de don Arnaldo Tello Macavilca (fue el sobrino de su bisabuelo), es tema más contemporáneo como nos cuenta don Arnaldo, dice que: Shinshu era un muchacho muy hábil y a la vez flojo y sucede que ya tenía los 18 años y no concluía su primaria; porque todos los años empezaba con buen empeño, pero cuando llegaba el mes de agosto se perdía en la fiesta patronal y quedaba retirado de la escuela; y como ya estaba viejo, por acuerdo lo pasaron a 5to año para que termine. Y ese año fueron de excursión a la ruinas de Choykoto para hacer la clase de historia, pero antes ordenó que comieran su fiambre. Sucede que case al final de la clase aparece Shinshu con una jarra lleno de prendas de oro y plata que había descubierto en una de los ambientes, debajo de una piedra laja que sonó al ser pisado; y frente el hallazgo el profesor habría quedado sorprendido y dijo: lo que ha encontrado Shinshu es delito grave que nadie debe saber y si alguien comenta a sus padres vendrán los gendarmes y nos llevarán de preso a todos, por eso nadie habla de nada y al final se ofreció esconderlos en secreto para que nadie se entere. Por lo que la clase terminó en juego y todos retornaron al pueblo sin alguna novedad y recién al final del año sacudió un revuelo a toda la población: la noticia de que Shinshu terminó con diploma y nadie se explicaba cómo era posible tal caso, aunque todos los alumnos sabían lo que sucedía, pero nadie habló de nada. Y recién el siguiente año inicia el problema para Shinsho, quien inexplicablemente empezó a secarse y al final del año llegó hueso y pellejo; frente a ello sus padres consultaron a las curanderas, quienes pasaron cuy y diagnosticaron que había sido chupado por los gentiles y recién de moribundo relata su hallazgo en las ruinas de Choykoto y también el engaño del profesor foráneo, quien ya había desaparecido y nunca más supieron de su paradero, mientras Shinsho muere y recién en el entierro todos sus compañeros relataron lo sucedido".

Luego nos comenta don Arnaldo, la muerte de Shinsho se debe a la acción del antimonio de los metales preciosos sacados sin protección; aunque la visión general de la población sigue siendo que los "awelos" o los "gentiles" dañan o enferman en cuanto se profana su espacio (ruinas) y se hurta sus objetos de pertenencia sin permiso o previo pago, similar a la cualidad de los dioses andinos que premia a los que le recuerdan con sus pagos o sanciona con la enfermedad o la muerte a aquellos perturbadores o delincuentes (huaqueros y los contrabandistas, cazadores de los animales sagrados o los aventureros fortuitos). En esta medida, el significado de la enfermedad o la muerte de los infractores por la acción homeopática o contaminante de los ancestros y/o dioses en el mundo andino fueron y es una suerte de control social a los culturicidios (huaqueros) y devastadores de la naturaleza, que sigue latente y al parecer, los mismos pobladores siempre relatan a los foráneos con mayor dramatismo distintos casos, como insinuando que tengamos más cuidado o no intentemos infringir las reglas o normas consuetudinarias establecidas que afectan no sólo a los transgresores, sino, también a la colectividad como el síndrome cultural.

13 Este caso habría sucedido antes que llegara la carretera a Huarochirí, aproximadamente en 1930 a 1935. 


\section{Propuestas antropológicas y arqueológicas de los recursos culturales y sistema de valores de Huarochirí}

\subsection{Antecedentes y fundamentación etno-histórica}

Huarochirí o "Guarochirí" fue uno de los repartimientos antiguos de Lima que ya se registra para 1561 (Hampe 1979), como uno de los mayores tributarios (de 4000 pesos) de la parte cisandina de Lima a diferencia de otros, lo que indica que tenía densidad poblacional tributaria en buenas condiciones sociales por su productividad agroganadera y factura textil para buen vestir y vivir. En 1577 el corregidor Dávila Briceño reorganiza toda la región cisandina de Lima en cinco repartimientos (Rostworowski 1978): "Mancos y Laraos, Hatun Yauyos, Huarochirí, San Mateo de Huanchor y los de Chaclla”, con su capital del distrito de Huarochirí, cuando habían más de 300 pueblos dispersos; por lo que, sólo Huarochirí estaría conformado por "cinco guarangas": los "Quinti, Langasica, Chaurima, Colcaruna y Checa” y para 1577 la composición varía con los: "Quinti, Colcaruna, Xica, Checa, Chaucarima y Sisicaya”. Y cuando Ávila (1966) procede con la extirpación de las idolatrías y recoge su manuscrito de ritos y tradiciones de Huarochirí para fines del siglo XVI, encuentra a una población en proceso de reducción por las guerras civiles de los españoles y también ya hablaban el español con su propio acento.

Y para 1711 (Rostworowski 1978) por la baja demografía recomponen con los pueblos de "San Lorenzo de Quinti, San Pedro de Huancaire, San Juan de Tantaranche y Santiago de Anchicaia", siempre encabezado por Huarochirí donde residían los gobernantes españoles y los caciques principales.

En la segunda década del siglo XX, Tello y Miranda (1923) registran algunos sitios arqueológicos de San Pedro de Casta y correlacionan con los mitos, fiesta del agua y el culto a los dioses andinos o Auquillos que, para ese entonces sigue latente y operante en la cosmovisión de los casteños. Es más, ubican el sitio Castillo y arguyen como el templo de Wallallo Qarwancho en su expansión y así como, las cualidades y atributos de este dios foráneo se reproduce en el actual Soqta Qori (Soctacuri) (Arroyo 2003), identificado como el principal Auquillo de San Pedro de Casta en oposición con su vecino y homólogo Wampu de Chaclla (Ortiz 1977).

"El Proyecto Huarochirí (1952-1955)" realiza estudios antropológicos como continuación del plan de investigaciones del Instituto de Etnología y Arqueología (Matos y otros 1955), dirigido por José Matos y sus alumnos (Guillén, Cotler, Soler y Boluarte) y con el apoyo decidido de Luis E. Valcárcel como Director del Instituto de Etnología y Arqueología y Decano de la Facultad de Letras de la UNMSM, significando el inicio de estudios y publicaciones de la "Biblioteca de Etnología del Perú", dentro del objetivo de enmarcar los resultados específicos de las comunidades agroganaderas sin la oposición y/o dependencia de las haciendas coloniales o republicanas. El resultado fue de publicarse como "Las actuales comunidades de indígenas: Huarochirí en 1955", en base a los estudios de las comunidades de Huarochirí, San Lorenzo de Quinti, San Pedro de Huancaire y en Santiago de Anchucaya, cuando entonces registran 28 comunidades agrupadas en 13 centros poblados concentrados en los distritos de Huarochirí, San Lorenzo de Quinti y de Sangalla, con una población total de unos 10 mil habitantes.

Después, con las sugerencias de Pierre Duviols en 1973 (Ortiz 1977) se inicia el estudio específico de la cosmovisión de los huarochiranos para ser contrastado con los mitos recopilados por Francisco de Ávila (1966), dirigido por Alejandro Ortiz, quien publica con el título "Huarochirí, cuatrocientos años después" en 1977, donde trata de mostrar las transformaciones religiosas con el análisis estructuralista más que significaciones. 
Duviols pregunta no sin razón “¿Dónde estaba el santuario de Pariacaca?” (en Varón y Flores 1997), donde, en algunas páginas, apertura el debate y el quehacer definido de carácter arqueológico y antropológico, con la preocupación etnohistórica de explicar las redes de los santuarios precolombinos basados en el sistema de parentesco de los dioses andinos, como formas de vinculación e integración de los pueblos y territorios andinos, como fue con el enseñoramiento de Pariaqaqa y su parentela en el territorio de la cisandina de Lima.

El reto propuesto por Duviols (1997) no se hizo esperar y en este caso por los profesionales jóvenes, porque ese mismo año Carlos Farfán dirige la exploración en compañía de César Astuhuamán (1998) y los estudiantes de arqueología de Villarreal y San Marcos, recorriendo el Camino Inka desde San Juan de Tantarache hasta el Cerro Portachuelo; mientras Espinoza y Castro habrían recorrido desde Jauja hasta Pachakamaq con el "Proyecto Caminos del Antiguo Perú". Y en 1998, Carlos Farfán y sus alumnos, prosiguieron con las exploraciones de la ruta.

Lo que indica que el territorio de los distritos sureños de Huarochirí siempre ha estado en la preocupación de los especialistas con distintos objetivos y de manera aislada. Por lo que requiere realizar un estudio sistemático de carácter interdisciplinario por los antropólogos y arqueólogos, para cruzar las informaciones etnoarqueológicas que posibiliten contrastar y ensamblar para su mejor comprensión y análisis de la historia cultural de los pueblos huarochiranos.

\subsection{Justificación y posible aporte antropológico}

La región cisandina de Huarochirí está cargada de muchos recursos culturales de carácter arqueológico, histórico y antropológico; porque cuenta con muchas evidencias arquitectónicas precolombinas alineadas al "Camino Sagrado de Pariaqaqa a Pachakamaq", "Camino Inka" desde la cabecera de Hatun Xausa de la cuenca de Mantaro a la yunga de la costa central y también, antiguos pueblos abandonados por la política colonial de las "Reducciones", que dieron origen a los nuevos pueblos y actuales distritos. Estos nuevos pueblos fueron ordenados bajo la égida de los "Santos Patrones" en sustitución a sus antiguos dioses, templos, oratorios y sin embargo, siguen ocupando el mismo territorio sagrado del "Dios Pariaqaqa", reutilizando los canales de riego y sistema de andenerías o terrazas agropecuarias en distintas condiciones y valoraciones, consciente o inconscientemente por la presión de la modernidad aculturante y alienante desde la colonia a hoy.

Por lo que amerita que un estudio sistemático de carácter antropológico y arqueológico permitirá recuperar su historia negada o relegada por el contexto político cultural-religioso y generar una terapia antropológica que eleve su autoestima con la finalidad de reconocer su identidad étnica que posibilite a un real desarrollo de su cultura y de su nación étnica, con orgullo y con derecho cultural. Lo que a su vez tendrá efecto multiplicador con propiedad y seguridad para generar el turismo que permita ingreso de divisas para la economía deteriorada de los pobladores de los distritos que conforman el territorio sureño de Huarochirí.

Para ello, con el material etnohistórico que venimos procesando y hay avances (Arroyo 2006) y el material etnográfico y arqueológico que recopilamos con el viaje en abril-2008, proponemos el siguiente "Proyecto Factible Interdisciplinario" para rescatar sus recursos culturales que posibiliten adecuadamente a promocionar y controlar el turismo zonal, regional, nacional e internacional, de manera organizada y concertada con todos los distritos que conforman la zona sur de Huarochirí. Para cuyo efecto, previamente se firmará un CONVENIO ACADÉMICO Y DE INVESTIGACIÓN la EAP de Antropología y la Facultad de Ciencias Sociales de la UNMSM con el Concejo Provincial y Distrital de Huarochirí, tendiente a desarrollar la 
investigación en relación al entrenamiento y práctica profesional de los estudiantes, por una parte y por la otra, el equipo de profesionales participantes se comprometerá a desarrollar charlas y conferencias para los alumno-docentes de los centros educativos del lugar y para la misma población huarochirana en relación al compromiso de las autoridades locales, con el resultado de los avances de la investigación; asimismo, con el objetivo y compromiso final de entregar un libro que condense y consolide el convenio para que siga adelante la relación interinstitucional de San Marcos y los Concejos Provinciales y Distritales de Huarochirí.

El proceso de la investigación delineamos en dos partes simultáneas y compartidas: estudios arqueológicos y antropológicos, que agruparan su atención en los siguientes aspectos centrales y temáticos:

\section{a) La Investigación Arqueológica}

a.1. Prospección, mapeo y valoración de los sitios arqueológicos de los distritos sureños.

a.2. Registro y mapeo de los canales, acueductos, reservorios y manantiales antiguos en relación a su uso continuo y de los nuevos canales que se empalman, desvían o se adicionan para el sistema hidráulico vigente.

a.3. Prospección y mapeo de la "Ruta Sagrada de Pariaqaqa a Pachakamaq" en relación a la descripción de los mitos de Francisco de Ávila y de la memoria colectiva de los actuales pobladores (mitos y relatos actuales).

a.4. Continuar y precisar la prospección y mapeo del "Camino Inka" que asciende de la yunga costeña de Lima y llega, pasando por la cisandina de Huarochirí y la montaña sagrada de Pariaqaqa, a la cabecera de Hatun Xauxa o Jauja del valle de Mantaro.

a.5. Precisar la localización y el mapeo del santuario y oratorios de Pariaqaqa y de los posibles sitios escenarios de la batalla de los dioses.

a.6. Registro y descripción del sistema ecológico en función a la ubicación de los asentamientos precolombinos para conocer el manejo del ecosistema.

\section{b. La investigación antropológica}

\section{Tradición andina}

b.1. Recopilación y análisis de los mitos y relatos andinos de los dioses, espíritus, héroes culturales y de los personajes: mitos de origen

b.2. Champería y el rito de limpieza en la toma y sistema de canales de riego actuales: su registro y mapeo

b.3. Sistema curativo y el registro de las plantas medicinales

b.4. La artesanía, el arte y el mercado

b.5. Registro y descripción de la tecnología agropecuaria

\section{Tradición andina-cristiana}

b.6. Registro y descripción de las fiestas santorales: mitos de fundación

b.7. Sistema de matrimonios y la red de parentescos

b.8. Calendario festivo por pueblos y distritos

b.9. Personalidades con la actividad político social 


\section{Bibliografía}

ANDERS, Martha

1989 “Azángaro: Estructura y función de un sitio planificado". En Boletín de Lima N. ${ }^{\circ}$ 64, Año II, julio, pp.15-32, Lima.

ARGUEDAS, José María

1981 Formación de una cultura nacional indoamericana. México: Edic. Siglo XXI.

ARROYO, Sabino

2006 Culto a los Hermanos Cristo. Lima: Universidad Nacional Mayor de San Marcos.

2005 "La cultura andina es patrimonio y tradición viva". En Revista de Antropología N. ${ }^{\circ}$ 3. Lima: Universidad Nacional Mayor de San Marcos.

2004a Dioses y oratorios andinos de Huancabamba. Lima: Universidad Nacional Mayor de San Marcos.

2004b "Los mitos como huellas del tiempo y contacto intercultural". En Revista de Antropología N. ${ }^{\circ}$ 2. Lima: Universidad Nacional Mayor de San Marcos.

2003 "Julio C. Tello y la antropología". En Investigaciones Sociales N. ${ }^{\circ} 11$. Lima: Universidad Nacional Mayor de San Marcos.

1987 Algunos aspectos del culto al Tayta Wamani. Lima: Universidad Nacional Mayor de San Marcos.

ASTUHUAMAN, César

1998 La ruta de los dioses y el adoratorio de Pariaqaqa. En Sequilao N. ${ }^{\circ}$ 12, Año VII, Lima.

[Inédita] Los otros Pariacaca: oráculos, montañas y parentelas sagradas.

ÁVILA, Francisco de

1966 Dioses y hombres de Huarochirí. Lima: MNH.

CIEZA DE, Pedro

1984 La crónica del Perú. Lima: Ed. Peisa.

DUNBAR, Ella

1978 Los caciques Apoalaia del valle del Mantaro. En Cuadernos Universitarios. Lima: Universidad Nacional Mayor de San Marcos.

DUVIOLS, Pierre

2002 ¿Dónde estaba el santuario de Pariaqaqa? En Arqueología, antropología e historia en los Andes. Lima: Instituto de Estudios Peruanos.

ISBELL, William y GORDON F. McEwan

1991 Huari Administrative Structure: Prehistoric monumental architecture and state government. Washington D.C. : Dumbar Oaks Research Library and Collection.

HAMPE, Teodoro

1979 Relación de los encomenderos y repartimientos del Perú en 1561. En Historia y cultura $\mathrm{N}^{\circ} 12$, pp. 75-117. Revista del Museo Nacional de Historia INC, Lima.

GOLTE, Jürgen

1994 La rebelión contra el dios sol. Lima: Instituto de Estudios Peruanos.

GRIFFITHS, Nicholas

1998 La cruz y la serpiente. Lima: Pontificia Universidad Católica del Perú.

GUAMÁN POMA, Felipe

1980 La nueva corónica y buen gopbierno. Siglo XXI-IEP, México.

MATOS, José y otros

[?] Las actuales comunidades de indígenas: Huarochirí en 1955. Lima: Instituto de Etnología de la Facultad de Letras de la UNMSM. 
MILLONES y otros

1990 El retorno de las Huacas. Instituto de Estudios Peruanos. Lima.

MOROTE, Efraín

1988 Aldeas sumergidas. Cusco: CERA Bartolomé de las Casas.

MURRA, John

2002 El mundo andino: población, medio ambiente y economía. Lima: Instituto de Estudios Peruanos y Pontificia Universidad Católica del Perú.

ORTIZ, Alejandro

1973 De Adaneva a Inkarrí. Lima: Ed. Retablo de Papel.

1977 Huarochirí, cuatrocientos años después. Lima: Pontificia Universidad Católica del Perú.

OSSIO, Juan

1973 Ideología mesiánica del mundo andino. Lima: Edic. Ignacio Prado.

POLIA. Mario

1999 La cosmovisión religiosa andina. Lima: Pontificia Universidad Católica del Perú.

ROSTWOROSWSKI, María

1978 Señoríos indígenas de Lima y Canta. Lima: Instituto de Estudios Peruanos.

TAYLOR, Gerald

2000 Camac, camay y camasca. Cusco: IFEA y CERA Bartolomé de las Casas.

1987 Ritos y tradiciones de Huarochiri del siglo XVII. Lima: Instituto de Estudios Peruanos.

TELLO, J. César

1967 Páginas escogidas. Lima: Universidad Nacional Mayor de San Marcos.

TELLO, J. César y MIRANDA, Próspero

1923 "Wallallo: ceremonias gentílicas realizadas en la región cisandina del Perú Central”. En Revista Inca N. ${ }^{\circ}$ II, vol I, Lima.

VARÓN, Rafael y Javier FLORES

1997 Arqueología, antropología e historia en los Andes (Homenaje a María Rostworowski). Lima: Instituto de Estudios Peruanos.

WACHTEL, Nathan

1976 Los vencidos: los indios del Perú frente a la conquista española (1530-1570). Madrid: Alianza Editorial. 